"نشريه علوم زراعى ايران"

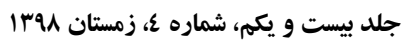

مقاله ئولشى

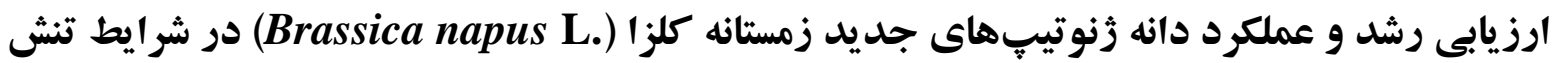
خشكى انتهاى فصل زمستانه

Evaluation of growth and seed yield of new winter oilseed rape (Brassica napus L.) genotypes under terminal drought stress conditions

$$
\begin{aligned}
& \text { عباس رضايى زاد'، اسداله زارعى سياه بيدى بو اميرحسين شيرانى رادّ } \\
& \text { جكيده }
\end{aligned}
$$

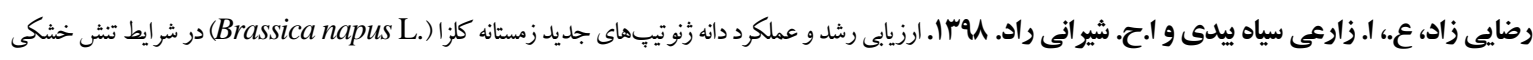

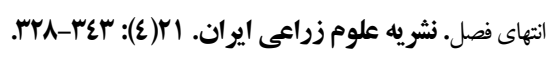

جكيده

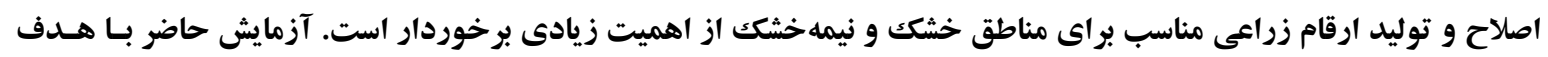

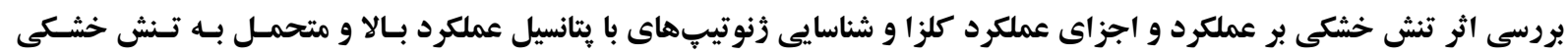

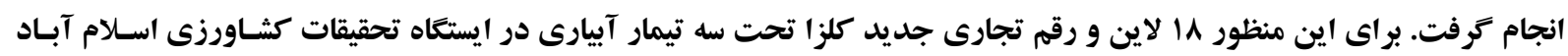

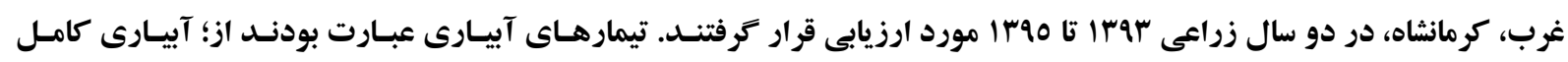

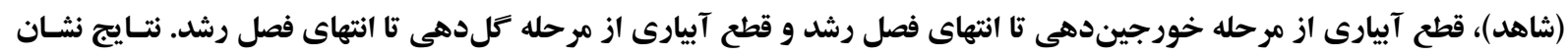

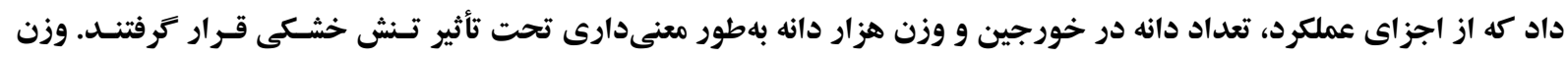

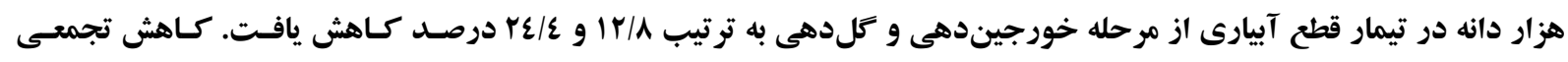

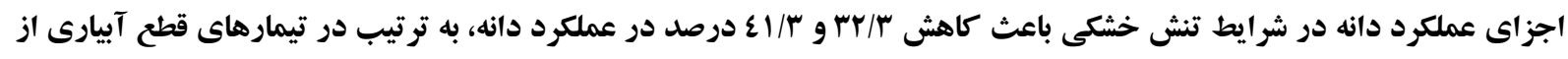

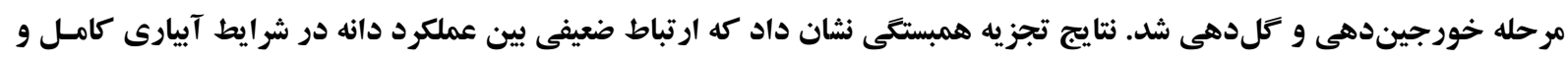

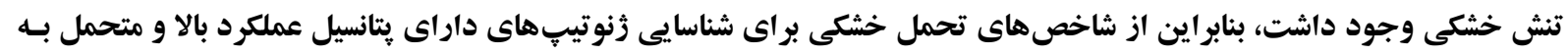

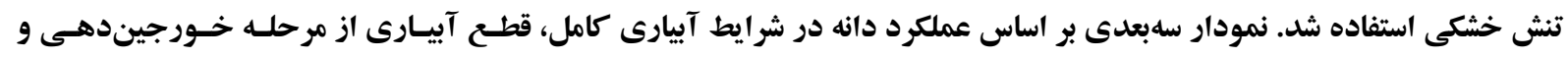

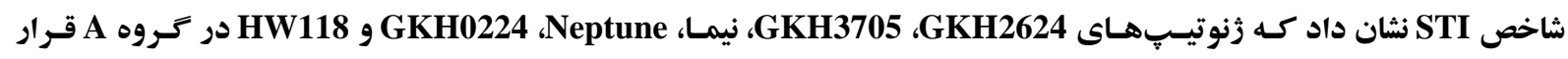

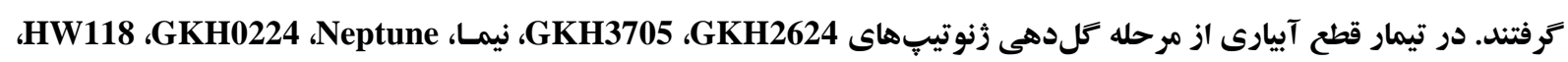

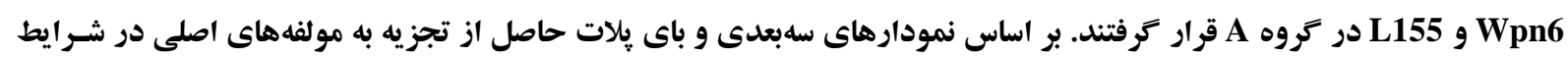

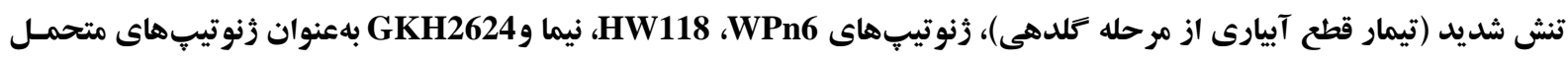
به تنش خشكى و با يتانسيل عملكرد بالا شناخته شدند.

وازههاى كليدى: باى بِات، تجزيه به مولفهاى اصلى، تنش خشكى، عملكرد دانه و كلزا.

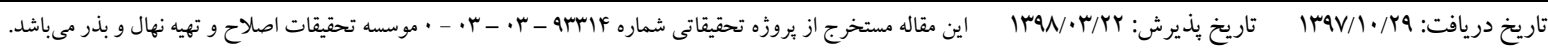

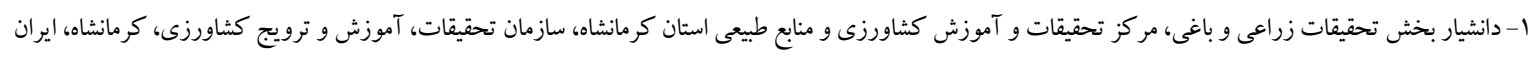
(مكاتبه كننده) (يست الكترونيك: (arezaizad@yahoo.com)

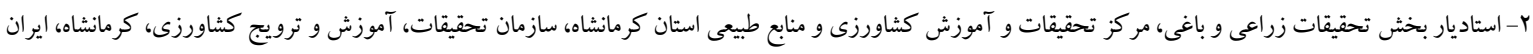

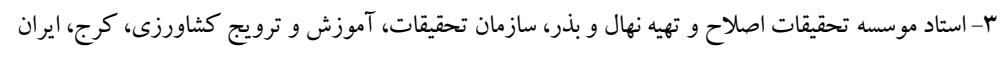


فيزيولوزيكى ييجيدهاى بوده و بيشتر اين فر آيندها تحت

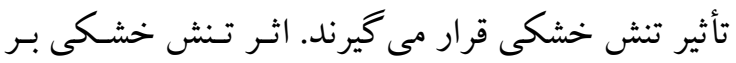

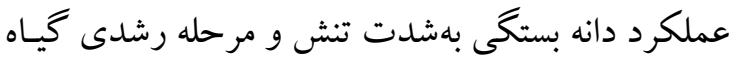

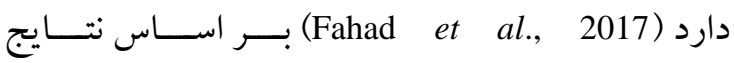
برخى آزمايشها، حساسترين زمان براى آبيارى كلنزا،

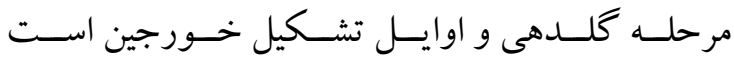
(Richard, 1978; Richard \& Thrling, 1978) آزمايش دلخوش و همكاران (Delkhosh et al., 2012)

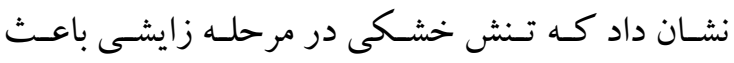

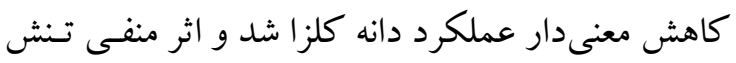
خشكى بر عملكرد دانه كمتر از تأخير در كاشـت بـوده. هنر و همكاران (Honar et al., 2013) در ارزيابى اثرات تنش در مراحل مختلف رشد كلز انشان دادند كه تيمـار ديم كامل و تنش در مرحله رسيدكَ به ترتيب بيشترين

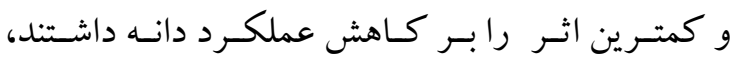
درحالى كه بيشترين حساسيت كلـزا مربـوط بـه تـنش در بين دو مرحله رشد رويشى مجدد و شروع كلدهى بـ بود.

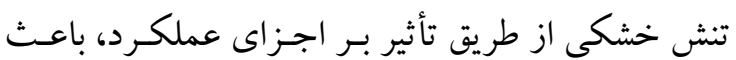
كاهش عملكرد دانه كلزا مىشـود. بطور كلـى در ميـان اجزاى عملكرد كلزا، تعداد خـورجين در بو تـه بيشترين

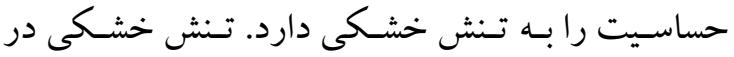

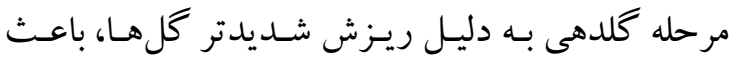
كـاهش قابل توجسه تعـداد خـورجين در بوتسه مىشـود (Sinaki et al., 2007) نتـايج آزمـايش دانشـمند و همكاران (Daneshmand et al., 2006) نشان داد كه اثر تنش خشكى بر عملكرد دانه كلـزا از طريـق كـاهش در تعـداد دانسه رخ داد. در آزمــايش قبــادى و همكــاران كاهش عملكرد دانه كلززادر (Ghobadi et al., 2006)

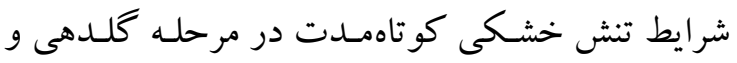
خورجين دهى حاصل كاهش تعداد خورجين در بوتسه و

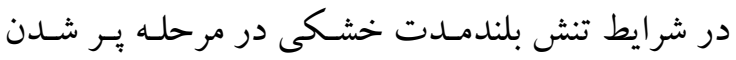
دانهها حاصل كاهش وزن دانه بود.

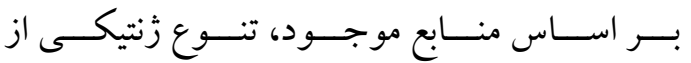

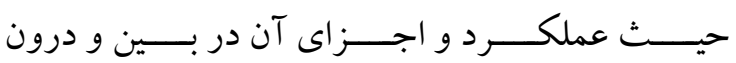

\section{مقدمه}

كلـزا بعـد از سـويا و نخـل روغنسى، سـومين گيـاه

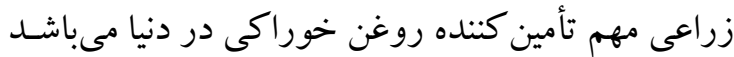

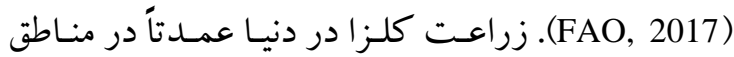
اصلى توليد آن، مبتنى بـر استفاده از نزولات رولات آسـمانى

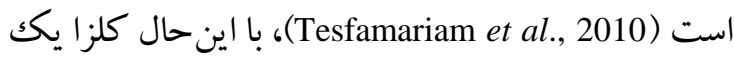

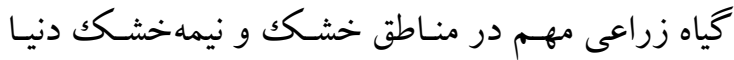

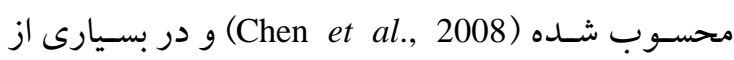

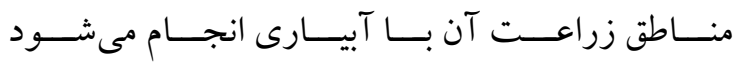
(Tesfamariam et al., 2010)

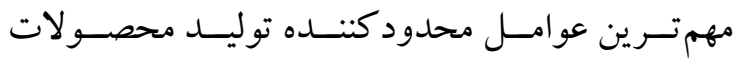

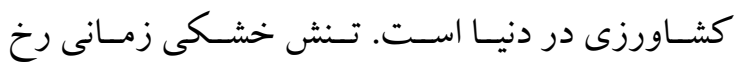

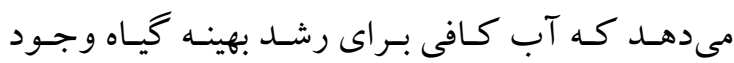

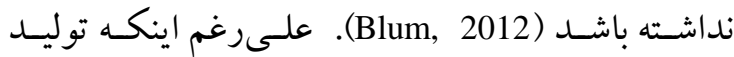

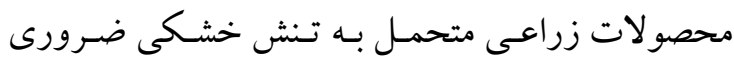

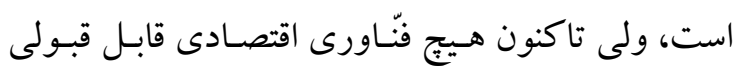
بـراى تسـهيل توليـد محصـولات در شـرايط تـنش ارائهـ

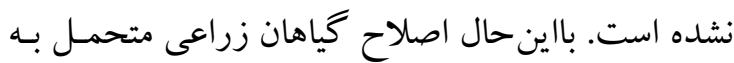
تنش خشكى بهعنوان يـك رويكـرد اميدوار كنتــده مـور توجه مىباشد (Farooq et al., 2009). در ايران گياه كلزا همانند گنــدم بـه هـر دو صسورت

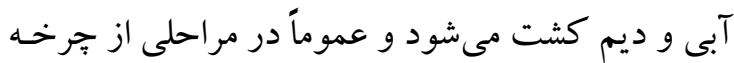

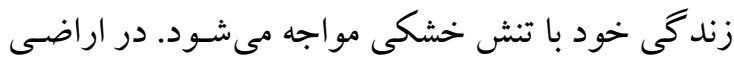
فارياب و مناطقى كه در آنها از آبهاى سطحى بـراى

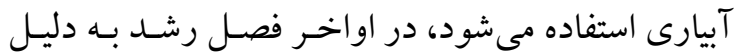

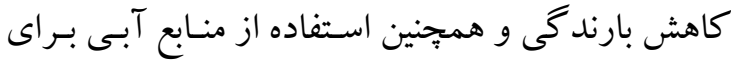
زراعتهاى برسود بهاره، ميزان آب قابل دسترس افـت شديدى مى يابد. در نتيجه فواصل آبيارى طولانى شده و

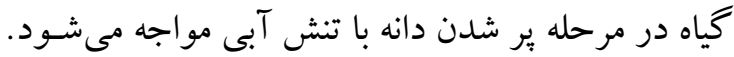

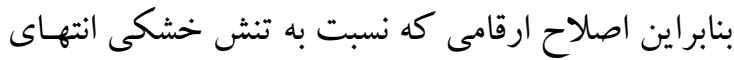

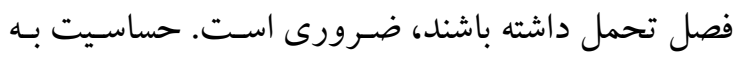

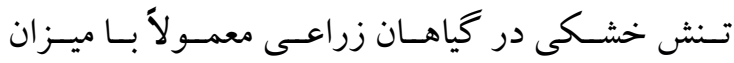
كاهش عملكرد دانسه سـنجيده مى شـود (Blum, 2012)

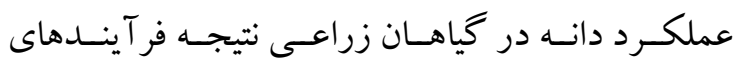


زمستانه كلزا و شناسـيـى زنوتيِهـاى متحمـل بـه تـنش خشكى انتهاى فصل از شهريور سهسا به مـدت دو سـال زراعى در ايستخاه تحقيقات كشاورزى اسلام آباد غـرب التهري

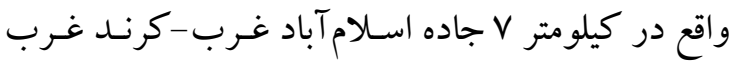

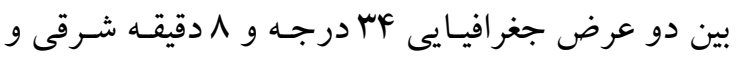

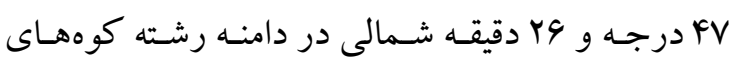

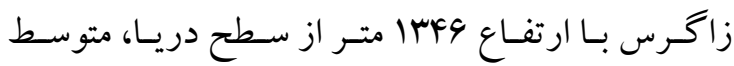

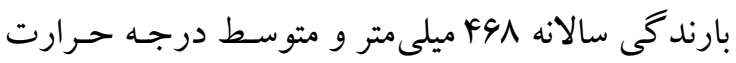

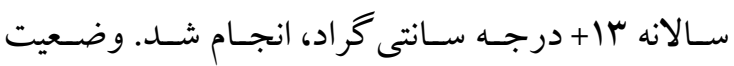
اقليمى ايستگاه مذكور طى دو سال آزمـايش در جـدول

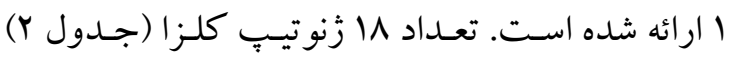
شامل ارقام و لاينهاى خـارجى و داخلـى در سـه تيمـار

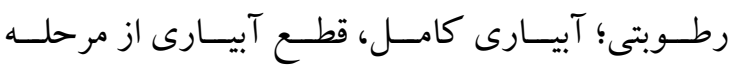

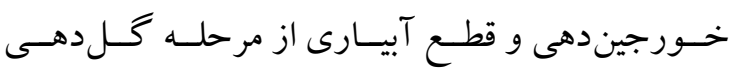

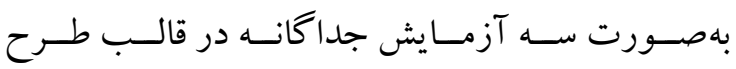

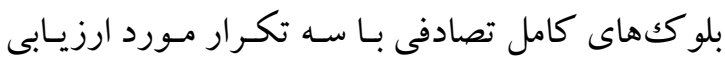

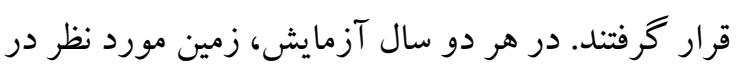

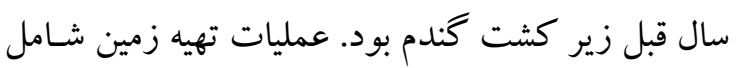
در شهريور انجام و بر اساس نتـايج آزمـون خـاكك، نيـاز

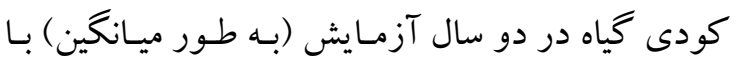

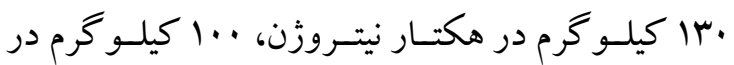

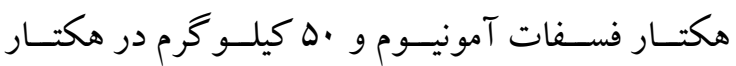
سولفات بتاسيم تامين شـد. تمـام كـود يتـاس و فسـفر و و يكك سوم از كود نيتروزن توصيه شده در زمان كاشت و و

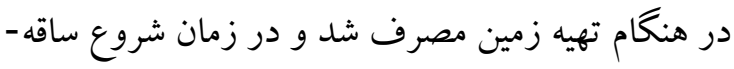

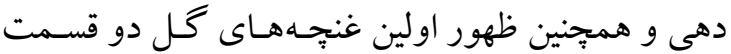
ديخر كود نيتروزن به خاكك داده شدند. براى آبيـارى از

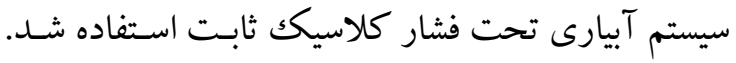

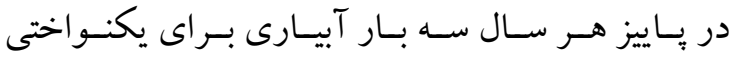

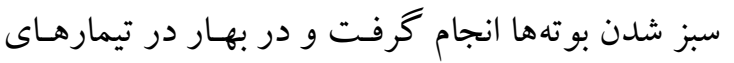

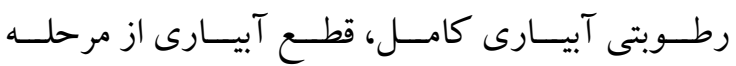

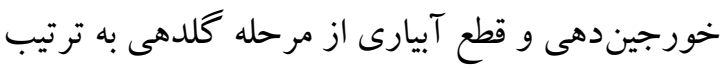

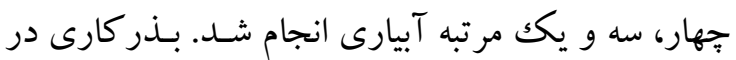

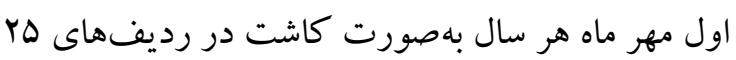

كونههاى براسيكا در شرايط تـنش خشكى وجـود دارد (Blum, 2012) و (Richard and Thrling, 1978) بلـوم (Pa) "بـانتوان و همكــاران (Pantuwan et al., 2002) بيـان داشتند كه عملكرد دانه فقط در شرايط تنش متوسط و

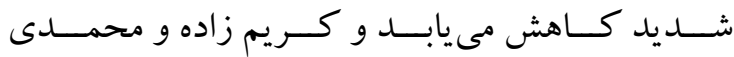
ي يشنهاد دادنــ (Karimzadeh and Mohammadi, 2011)

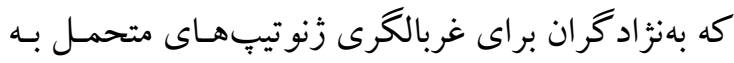

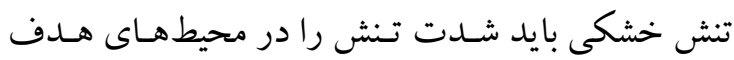
در نظر بخيرند. در حال حاضر بيشترين سطح زيـر كثـت كلـزا در

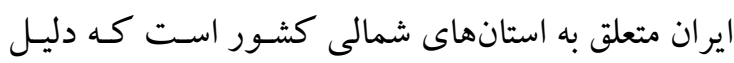

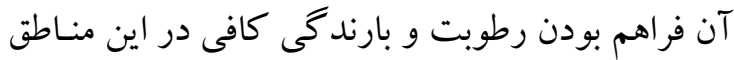
است. با اين حال مناطق سرد و معتدل سرد كشور همانند

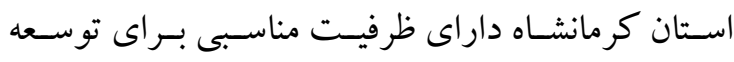
زراعت كلزا هستند. در ايـن منـاطق يكى از مشكلات

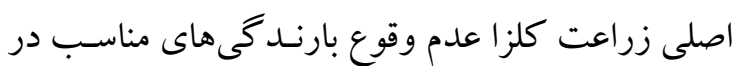

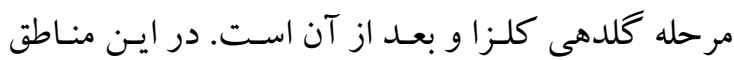

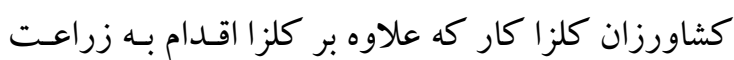

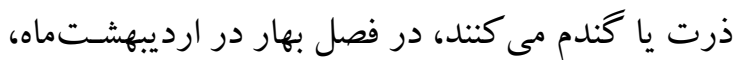

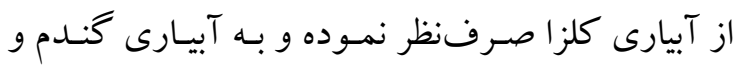
ذرت مى يردازند. قطع آبيارى كلزا در اين مرحله مقــارن

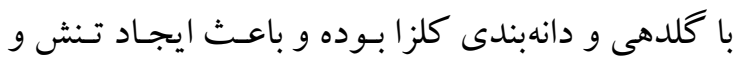
كاهش محصول مىشود؛ بنابر اين شناسايى زنوتيبهـاى متحمل به تنش خشكى انتهاى فصـل در ايـن منـاطق از

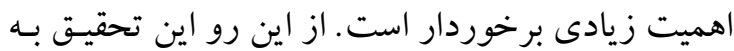

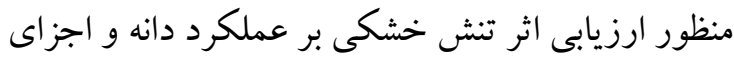

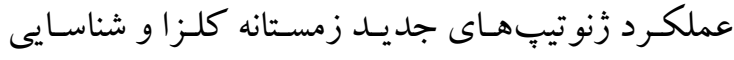

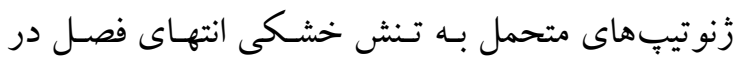

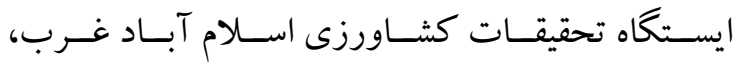
كرمانشاه، طراحى و اجر ا شد.

\section{مواد و روشها}

آزمايش حاضر بهمنظور بررسى اثر تنش خشكى بـر

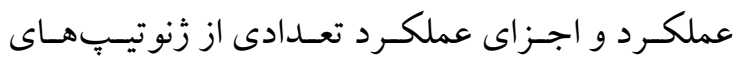


D (شـدت تــش ) بـا اسـتفاده از رابطـه 9 محاسـبه

مى شود:

$\mathrm{D}=1-(\overline{\mathrm{Y}} \mathrm{s} / \overline{\mathrm{Y}} \mathrm{p})$

(رابطه (9)

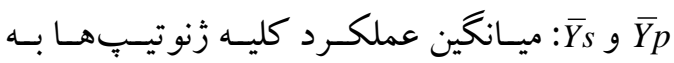

ترتيـــب در شـــرايط بــــون تـــش و تـــش هســـتند

(Fischer and Maurer, 1978)

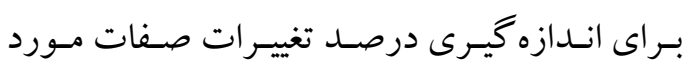

ارزيابى در شرايط تنش نسبت به شـرايط بـدون تسنش از رابطه V استفاده شد.

Changes $(\%)=(Y p-Y s) / Y p) \times 100 \quad($ ر ر ابطه $)$

Y و YP

بدون تنش و تنش خشكى هستند.

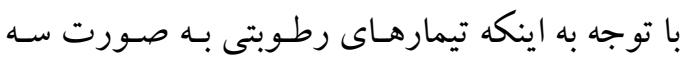

آزمايش جداگانه در نظر كرفته شـدند، از روش تجزيـه

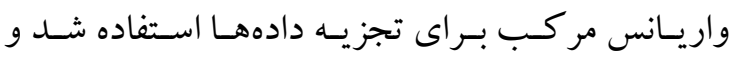

آزمون F براى معنى دار بودن منابع تغييرات با استفاده از

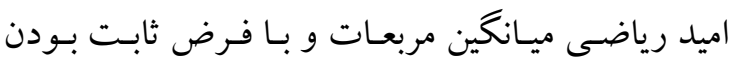
تيمارهاى رطوبتى (محيط) به عنوان فاكتور ثابت و سـال

به عنوان فاكتور تصادفى انجام شد.

براى تجزيه واريانس دادهها از نرمافزار SAS و براى

تجزيسـه بــه مؤلفــهاى اصــلى و رســم بــاىيـلات از

نرمافزارهاى Minitab و SPSS استفاده شد.

\section{نتايج و بحث}

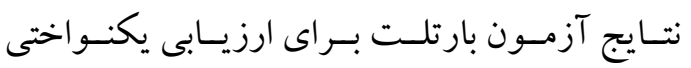

اشتباهات آزمايشـى نشـان دهنـده يكنـو اختى اشـتباهات

آزمايشى براى صفات مـورد بررسىى بـود، بـا ايـن حسال

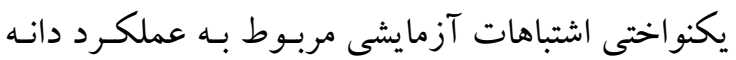

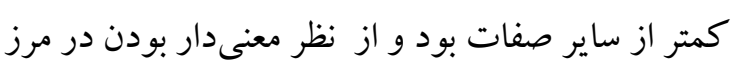
تصميم كيرى قرار كرفت. نتايج نشان داد كه اثر سال بر عملكرد دانه و اجززاى

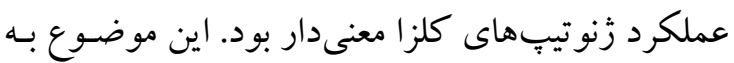

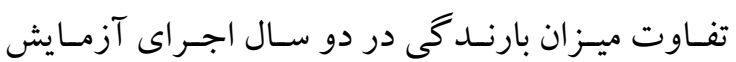

سانتى مترى روى بِشتههاى از قبل آمادهشـده انجـام شـد. هر كرت آزمايشى شامل جهار خط كاشت به طول يـنج متر و مساحت ينج مترمربع بود. براى مبارزه با شته مومى هـ از آفـت كث سيسـتميكك متاسيستو كس (يـك ليتـر در

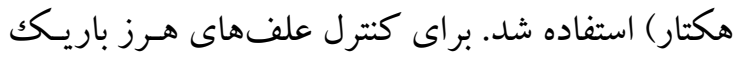
بركَ از علف كش سـوير گالانت بـه ميزان ^/ • ليتـر در هكتـار اسـتفاده شـد و علـف هــاى هـرز بهن.بـر كَ نيـز بهصورت وجـين دستى كنتـرل شـدند. در طـول فصـل زراعى اجزاى عملكـرد دانـه شـامل تعـداد خـورجين در بوته و تعداد دانه در خورجين يادداشـتبردارى شـــ. در

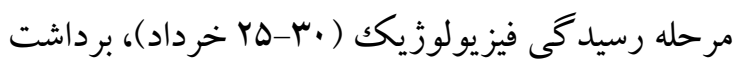
محصول بـا حـذف نـيم متــ از دو انتهـاى كرت انجـام كرفت و عملكرد دانه زنوتيٍٍا بر اساس رطوبـت دانسه

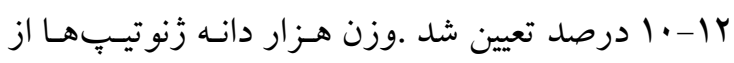

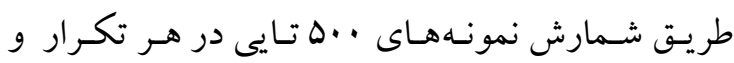
توزين آن بر حسب كرم اندازه گيرى شد. براى ارزيـابى

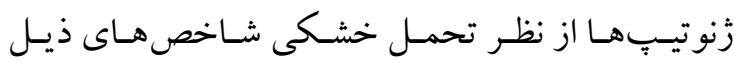

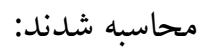

شـاخص تحمل (Rosielle and Hamblin, (TOL)

$\mathrm{TOL}=\mathrm{Yp}-\mathrm{Ys}$

(رابطه ()

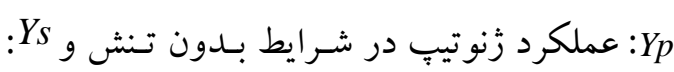
عملكرد زْنو تيّ در شر ايط تنش هستند. ميـانگين حسـابى (Rosielle and Hamblin, (MP)

$\mathrm{Mp}=(\mathrm{Yp}+\mathrm{Ys}) / 2$

(رابطه (r)

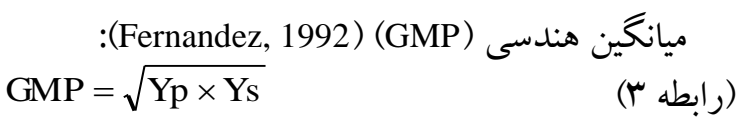

شاخص تحمل تنش (STI) (Fernandez, 1992):

$$
\begin{aligned}
& \mathrm{STI}=(\mathrm{Yp} \times \mathrm{Ys}) /(\overline{\mathrm{Y}} \mathrm{p})^{2} \\
& \text { (رابطه أ) } \\
& \text { شاخص حساسيت به تنش (SSI): } \\
& \mathrm{SSI}=1-(\mathrm{Ys} / \mathrm{Yp}) / \mathrm{D}
\end{aligned}
$$




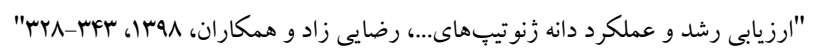

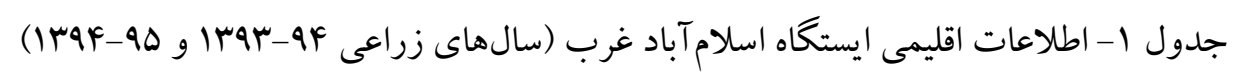

Table 1. Meteorological information of Islamabad-e-Gharb Research Station, Iran (2014-15 and 2015-16 growing seasons)

irar-ap

$1+49-9 D$

los $\left({ }^{\circ} \mathrm{C}\right)$

2015-2016

$\begin{array}{cc}\text { los } & \text { los } \\ \text { Temperature }\left({ }^{\circ} \mathrm{C}\right) & \text { Temperature }\left({ }^{\circ} \mathrm{C}\right)\end{array}$

\begin{tabular}{|c|c|c|c|c|c|c|c|c|c|}
\hline \multirow[b]{2}{*}{ Month } & \multirow[b]{2}{*}{ ماه } & \multicolumn{3}{|c|}{ (5) } & \\
\hline & & $\begin{array}{c}\text { متوسط } \\
\text { Average }\end{array}$ & 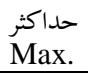 & حاقل & (mm) Precipitation & $\begin{array}{c}\text { متوسط } \\
\text { Average }\end{array}$ & حax. & حاقل & (mm) Precipitation \\
\hline Sep.-Oct. & مه & 16.9 & 30.4 & 1.4 & 40.9 & 19.0 & 33.4 & 2.4 & 3.4 \\
\hline Oct.-Nov. & آبان & 8.7 & 22.4 & -4.2 & 61.5 & 10.0 & 26.2 & -0.4 & 266.2 \\
\hline Nov.-Dec. & آذر & 6.2 & - & - & 38.2 & 3.3 & 18.0 & -11.4 & 60.4 \\
\hline Dec- Jan. & دى & 2.4 & 14.8 & -8.8 & 31.2 & 3.1 & 15.4 & -8.6 & 67.7 \\
\hline Jan.-Feb. & re & 6.3 & 18.6 & -0.8 & 20.7 & 3.2 & 10.0 & -8.8 & 68.3 \\
\hline Feb.-Mar. & أسفند & 5.9 & 20.2 & -6.4 & 46.5 & 9.0 & 19.0 & -3.0 & 85.2 \\
\hline Mar.-Apr. & فروردين & 16.5 & 27.4 & -1.6 & 58.1 & 9.6 & 22.6 & -2.8 & 137.6 \\
\hline Apr.-May & اردبيششت & 17.4 & 32.8 & -1.2 & 9.7 & 16.3 & 31.8 & 1.8 & 39.8 \\
\hline May-Jun. & خ خدراد & 24.5 & 37.4 & 9.4 & 0.0 & 19.6 & 33.6 & 5.8 & 0.0 \\
\hline
\end{tabular}

جدول r- نام، منشأ و تيب رشد زنوتيبهاى زمستانه كلزا

Table 2. Name, origin and type of winter oilseed rape genotypes

\begin{tabular}{|c|c|c|c|c|c|}
\hline 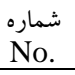 & $\begin{array}{c}\text { زُنوتِبِهاى كلزا } \\
\text { Oilseed rape genotypes } \\
\end{array}$ & 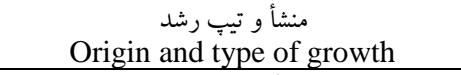 & $\begin{array}{l}\text { شماره } \\
\text { No. }\end{array}$ & $\begin{array}{c}\text { رُنوتيبِهاى كلزاى } \\
\text { Oilseed rape genotypes }\end{array}$ & 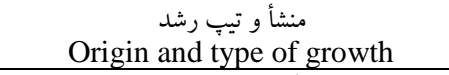 \\
\hline 1 & OPERA & $\begin{array}{c}\text { رقم آزاد گرده افشان- سوئد } \\
\text { Sweden open pollinated cultivar }\end{array}$ & 10 & GABRIELLA & $\begin{array}{c}\text { رقم آزادگرده افشان-مجارستان } \\
\text { Hungarian open pollinated cultivar }\end{array}$ \\
\hline 2 & Ahmadi & $\begin{array}{c}\text { رقم آزاد گرده افشان-ايران } \\
\text { Iranian open pollinated cultivar }\end{array}$ & 11 & NEPTUNE & $\begin{array}{c}\text { رقم هيبريد- فرانسه } \\
\text { French Hybrid cultivar }\end{array}$ \\
\hline 3 & Nafis & $\begin{array}{c}\text { رقم آزاد گرده افشان-ايران cultivar } \\
\text { Iranian open pollinated }\end{array}$ & 12 & ELVISE & $\begin{array}{c}\text { رقم هيبريد-فرانسه cultivar } \\
\text { French Hybrid cul }\end{array}$ \\
\hline 4 & Nima & $\begin{array}{c}\text { رقم آزاد گرده افشان-ايران } \\
\text { Iranian open pollinated cultivar }\end{array}$ & 13 & HW118 & $\begin{array}{c}\text { لاين آزاد گرده افشان-ايران Line } \\
\text { Iranian open pollinated Line }\end{array}$ \\
\hline 5 & KARAJ1 & $\begin{array}{c}\text { لاين آزادكرده افشان- ايران } \\
\text { Iranian open pollinated Line }\end{array}$ & 14 & HL2012 & 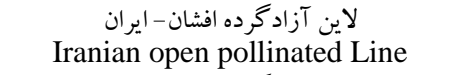 \\
\hline 6 & OKAPI & $\begin{array}{c}\text { رقم آزادگرده افشان-ايران } \\
\text { Iranian open pollinated cultivar }\end{array}$ & 15 & WPN6 & $\begin{array}{c}\text { لاين آزاد گرده افشان- ايران Line } \\
\text { Iranian open pollinated Line }\end{array}$ \\
\hline 7 & GKH3705 & $\begin{array}{c}\text { رقم آزادكرده افشان- مجارستان } \\
\text { Hungarian open pollinated cultivar }\end{array}$ & 16 & L155 & $\begin{array}{c}\text { لاين آزاد گرده افشان-ايران } \\
\text { Iranian open pollinated Line }\end{array}$ \\
\hline 8 & GKH2624 & $\begin{array}{c}\text { رقم آزادگرده افشان-مجارستان } \\
\text { Hungarian open pollinated cultivar }\end{array}$ & 17 & HL3721 & $\begin{array}{c}\text { لاين آزاد گرده افشان- ايران } \\
\text { Iranian open pollinated Line }\end{array}$ \\
\hline 9 & GKH0224 & $\begin{array}{c}\text { رقم آزاد كرده افشان- مجارستان } \\
\text { Hungarian open pollinated cultivar }\end{array}$ & 18 & KARAJ2 & $\begin{array}{c}\text { لاين آزادگرده افشان-ايران } \\
\text { Iranian open pollinated Line }\end{array}$ \\
\hline
\end{tabular}


.(Shirani Rad and Zandi, 2012) اثر تنش خشكى در بين اجـزاى عملكـرد، بـر تعـداد

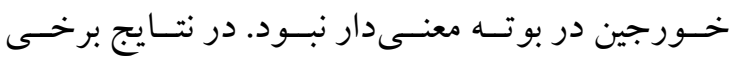
آزمايش ها بـه وراثت بـذيرى بـايين تعـداد خـورجين در بوته در كلزا اشاره شده است، زيرا ايسن صـفت بهشـدت تحت تأثير عو امل محيطى اسـت (Diepenbrock, 2000). اما برهمكنش سـال در تسنش خشـكى بـراى ايسن صـفت معنى دار بود، بهطورى كه در سـال اول تعـداد خـورجين در بوته در شرايط قطع آبيارى از مرحله خـورجين دهى

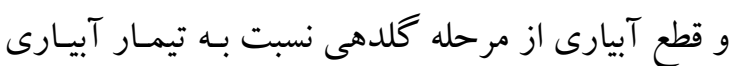

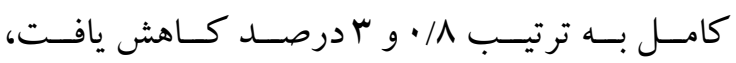
درحالى كه در سال دوم اين ميزان به ترتيب r/9 و س/ •r درصــ بــود. علـىرغم بارنسد كى بيشـتر در سـال دوم

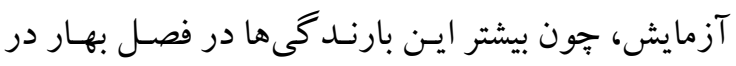
اوايل فروردين و قبـل از مرحله كلـدهى كلـا صـورت كرفت، در نتيجه تاثيرى بر تخفيف اثـر قطع آبيـارى از مرحله كلدهى بـر تعـداد خـورجين در بوتهـ نداشـتـ. از

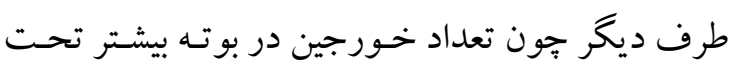
تأثير تنش در دوره كلدهى قرار مى گيرد، بنابر اين در اثر اعمال تنش در مرحله خورجين دهى (و تـامين رطوبـت

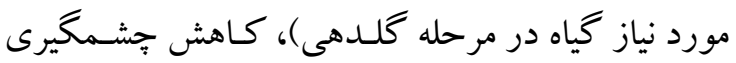
در تعداد خورجين در بوته مشـاهده نشـد. ايسن موضسوع توسط جبـارى و همكاران (Jabbari et al., 2015) نيـز كزارش شده است. در اين خصوص قبـادى و همكـاران كـزارش دادنــ كـه كـاهش (Ghobadi et al., 2006) عملكرد كلزا در شرايط تنش خشكى در مرحله كلدهى و خورجيندهى باعث كاهش تعـداد خـورجين در بوتسه شد، اما در شرايط تنش خشكى بلندمــــ در زمـان بـر شدن دانه، ناشى از كاهش وزن هزار دانسه بـود. كـاهش تجمعى اجزاى عملكرد در شرايط تسنش خشـكى باعـث كاهش معنى دار عملكرد دانه شد. كاهش عملكـرد دانسه بهمراتب بيش از كاهش تكك تكك اجز اى عملكـرد بـود، بهطورى كه اين كاهش در شرايط قطع آبيارى از مرحله.

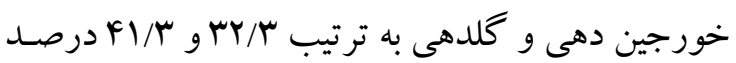

بر مى گردد، بهطورى كه ميـانگين بارنسدگى در سـال

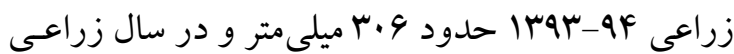

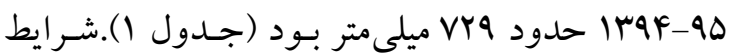

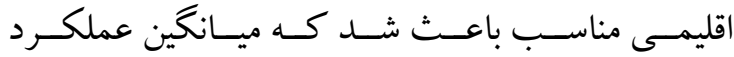
زَنوتيبهاى كلزا در سال دوم آزمايش ( IFDF كيلو كرم در هكتــار ) بهصـورت معنـى اردى بيشــتر از ســال اول آزمايش (MYV) در خصوص اجزاى عملكرد نيز صادق بود، بهطورى كـه ميانگين تعداد خورجين در بوته، تعداد دانه در خورجين

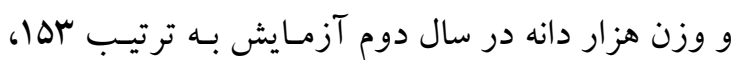

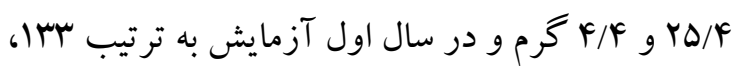
/ در خورجين و وزن هزار دانسه بـهور معنسى دارى تحـت تأثير تنش خشكى قرار كر فتند.

نتايج نشان داد كه وزن هزار دانه در مقايسه با تعـداد دانه در خورجين در اثر تسنش خشكى كـاهش بيشـترى داشـت، بهطورى كـه در شـرايط قطع آبيـارى از مرحلـه خورجيندهى و قطع آبيارى از مرحله كلدهى نسـبت بـه

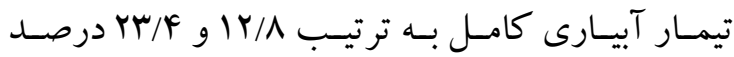
كاهش يافت، اين كاهش براى تعداد دانسه در خـورجين به ترتيب V/ V/ و V/ه درصد بـود. بـه نظـر مىرســ كـه تنش خشكى، بهويزه در شـرايط قطع آبيـارى از مرحلـه خورجين دهـى بـه بعـد تـأثير كمتـرى بـر تعـداد دانسه در خـورجين دارد، زيسـا تعـداد دانسه در خـورجين قبـل از اعمال تنش تعيين شده و تنش خشكى فقط باعـث سـط تعداد كمى از اين دانهها شده است؛ اما اين وضـعيت در مورد وزن هزار دانه متفاوت است و تنش خشكى در هر دو مرحله مصادف با دوره برشــدن دانسه اسـت. در دوره يرشدن دانه تنش خشكى باعث اختلال شـــيد در رونــ طبيعى يرشدن دانـه مى شـود و در نتيجـه وزن هـزار دانـه بهشدت كاهش بيدا مى كنــ. تـنش خشـكى در مراحـل كلدهى و يرشدن دانه از طريق قطع فتوسنتز كياه، توليـد مو اد برورده مورد نياز براى بر شدن دانه را كـاهش داده

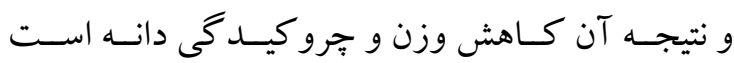




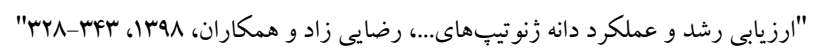

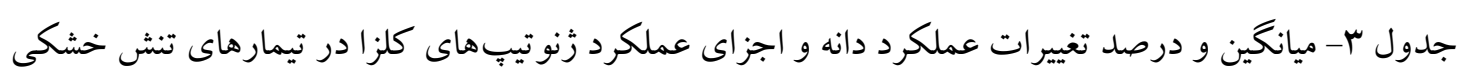

Table 3. Mean and variation of seed yield and yield components of oilseed rape genotypes in drought stress treatments

\begin{tabular}{|c|c|c|c|c|c|}
\hline \multirow[b]{2}{*}{ Treatments } & \multirow[b]{2}{*}{ تيمارهاي آزمايشى } & \multicolumn{4}{|c|}{ ميانگين Mean } \\
\hline & & $\begin{array}{c}\text { خورجين در بوته } \\
\text { Silique.plant }\end{array}$ & $\begin{array}{c}\text { عملكرد دانه } \\
\text { Seed yield }\left(\mathrm{kg} \cdot \mathrm{ha}^{-1}\right)\end{array}$ & $\begin{array}{c}\text { وزن هزار دانه } 1000 \text { Seed weight (g) } \\
\end{array}$ & $\begin{array}{l}\text { دانه در خورجين } \\
\text { Seed.silique }\end{array}$ \\
\hline Full irrigation & آبيارى كامل & 150.0 & 5174 & 4.7 & 25.2 \\
\hline Irrigation withhold from silique development stage & قطع آساري از خورجين دهى. & 147.0 & 3501 & 4.1 & 24.2 \\
\hline Variation compared to full irrigation $(\%)$ & تغييرات نسبت به آبيارى كامل & 2.0 & 32.3 & 12.8 & 3.97 \\
\hline Irrigation withhold from flowering stage & قطع آبيارى از غلدهى & 131.0 & 3038 & 3.6 & 23.3 \\
\hline Variation compared to full irrigation $(\%)$ & تغيير ات نست به آباري كامل & 12.7 & 41.3 & 23.4 & 7.50 \\
\hline
\end{tabular}

$$
\text { جدول F- شاخصهاى تحمل خشكى در زنو تيبٍ هاى كلزا در تيمار قطع آبيارى از مرحله خورجيندهى }
$$

\begin{tabular}{|c|c|c|c|c|c|c|c|c|}
\hline شماره & $\begin{array}{c}\text { رنوتيبهاى كلز } \\
\text { Oilseed rape genotypes }\end{array}$ & Yp & Ys & TOL & MP & SSI & GMP & STI \\
\hline 1 & OPERA & 5081 & 3347 & 1734 & 4214 & 1.07 & 4124 & 0.64 \\
\hline 2 & Ahmadi & 4388 & 3304 & 1084 & 3846 & 0.77 & 3807 & 0.54 \\
\hline 3 & Nafis & 4981 & 4020 & 961 & 4500 & 0.6 & 4475 & 0.75 \\
\hline 4 & Nima & 5614 & 3782 & 1831 & 4698 & 1.02 & 4608 & 0.79 \\
\hline 5 & KARAJ1 & 4788 & 3130 & 1658 & 3959 & 1.08 & 3871 & 0.56 \\
\hline 6 & OKAPI & 4410 & 3278 & 1132 & 3844 & 0.8 & 3802 & 0.54 \\
\hline 7 & GKH3705 & 5167 & 4233 & 934 & 4700 & 0.57 & 4676 & 0.82 \\
\hline 8 & GKH2624 & 5365 & 4282 & 1083 & 4823 & 0.63 & 4793 & 0.86 \\
\hline 9 & GKH0224 & 5621 & 3596 & 2025 & 4608 & 1.13 & 4496 & 0.76 \\
\hline 10 & GABRIELLA & 4719 & 3086 & 1633 & 3902 & 1.08 & 3816 & 0.54 \\
\hline 11 & NEPTUNE & 5259 & 3711 & 1548 & 4485 & 0.92 & 4418 & 0.73 \\
\hline 12 & ELVISE & 4715 & 3329 & 1386 & 4022 & 0.92 & 3962 & 0.59 \\
\hline 13 & HW118 & 6064 & 3497 & 2567 & 4780 & 1.32 & 4605 & 0.79 \\
\hline 14 & HL2012 & 5535 & 3145 & 2390 & 4340 & 1.35 & 4173 & 0.65 \\
\hline 15 & WPN6 & 5842 & 3357 & 2485 & 4599 & 1.33 & 4428 & 0.73 \\
\hline 16 & L155 & 5247 & 3457 & 1790 & 4352 & 1.07 & 4259 & 0.68 \\
\hline 17 & HL3721 & 4973 & 3100 & 1873 & 4036 & 1.18 & 3926 & 0.58 \\
\hline 18 & KARAJ2 & 5362 & 3358 & 2004 & 4360 & 1.17 & 4243 & 0.67 \\
\hline
\end{tabular}

Table 4. Drought tolerance indices of oilseed rape genotypes in irrigation withhold from silique development stage treatment

Yp: Yield potential, Ys: Yield under irrigation withhold, GMP: Geometric Mean Productivity, SSI: Stress Susceptibility Index, STR: Stress Tolerance Index, TOL: Tolerance Index, MP: Mean Productivity 
براى معرفى بهعنوان رقم جديد مى گذر اند. هيبريـدهاى

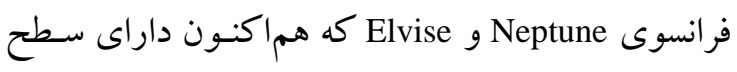
زير كشت زيادى در مناطق سـرد و معتـدل سـرد كشـور

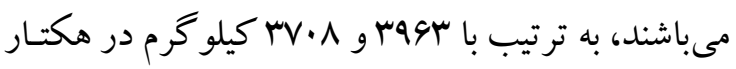
در رتبههاى 9 و سا عملكرد دانه قرار گرفتند. نتسايج تجزيـه همبسـتخى نشـان داد كـه رابطهـ نسبتاً

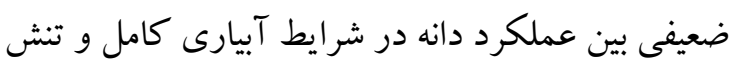

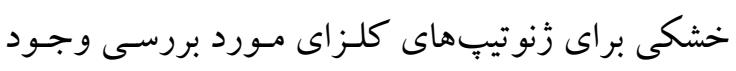

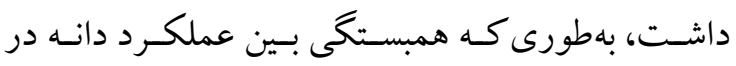

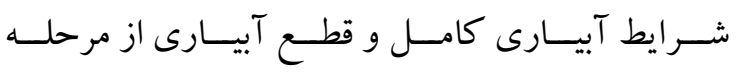

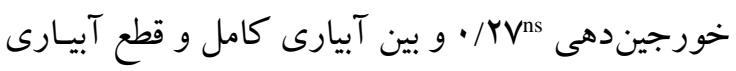

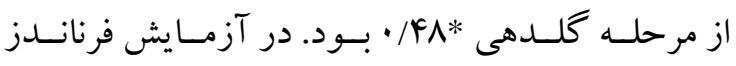

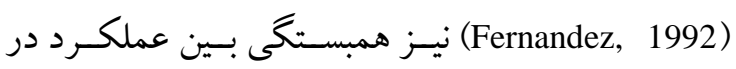

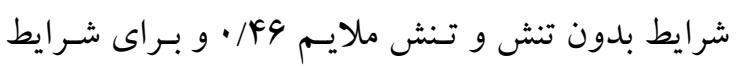

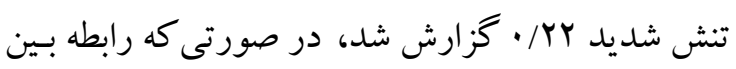
عملكرد در شرايط بدون تنش و تسنش خشكلكى برابـر بـا

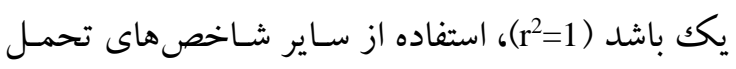

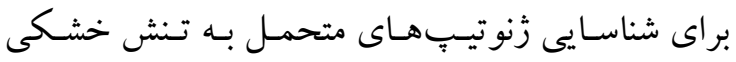

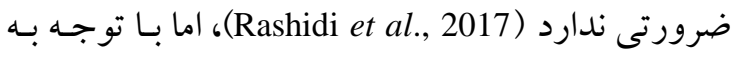
همبستكى ضعيف بين عملكرد دانسه در شـرايط تـنش و

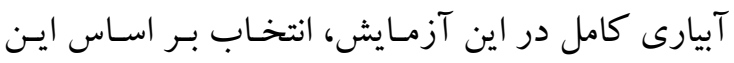

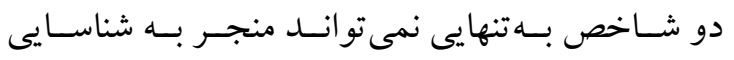

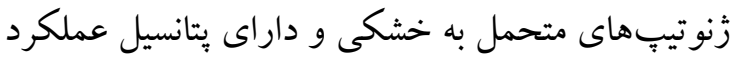

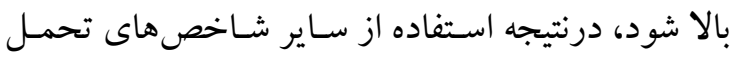

$$
\text { خشكى ضرورى است. }
$$

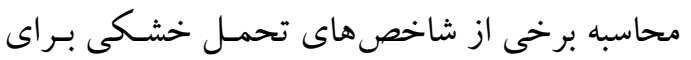

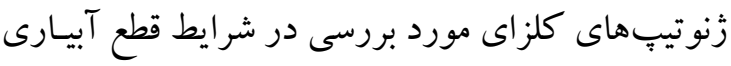

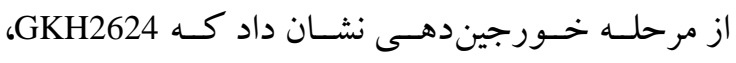

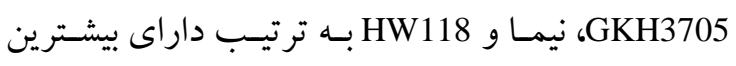

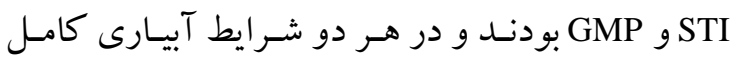

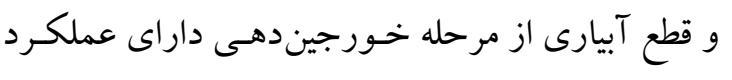

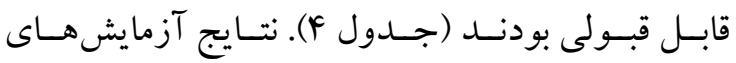

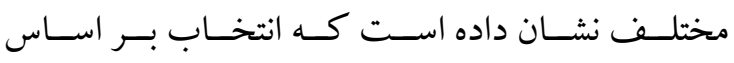
شاخصهاى GMP و STI منجر به انتخاب زنو تيسِهـاى

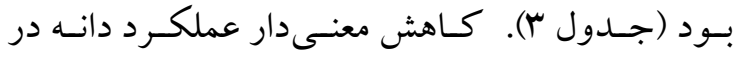
تيمارهاى رطويتى با قطع آبيارى از مرحله زايشى نشـان

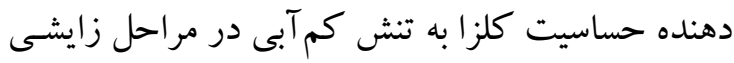

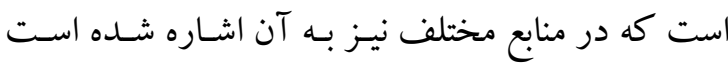
(Shampolivier and Merrien, 1996; Shirani rad and .Zandi, 2012; Hamed et al., 2014) اثر تنش خشكى بر عملكـرد گيـاه بستـى بهشـدت تنش و مرحله رشـدى گيـاه دارد (Fahad et al., 2017).

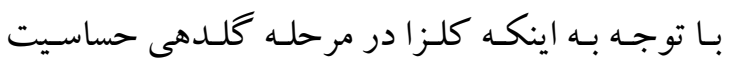
بيشترى به تنش خشكى دارد و با قطع آبيـارى از مرحلـه

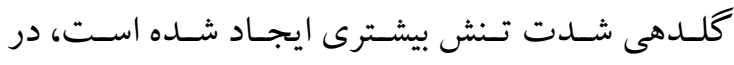
نتيجه ميزان كـاهش عملكـرد در تيمـار قطع آبيـارى از

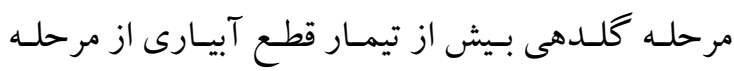
خورجين دهى مىباشد. در آزمايش قبـادى و همكـاران (Ghobadi et al., 2006)

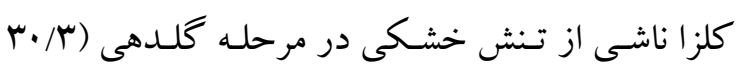

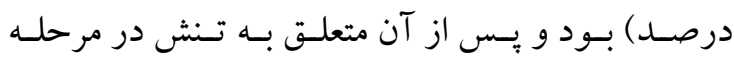

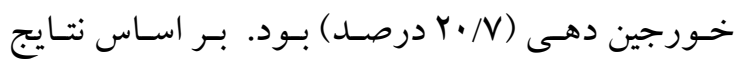

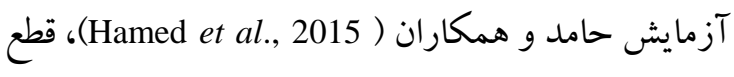

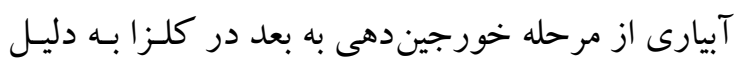

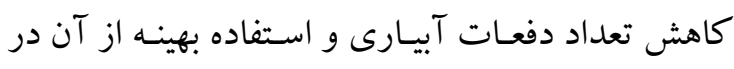

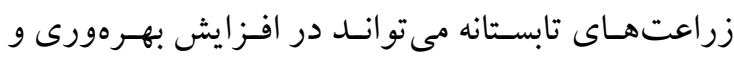

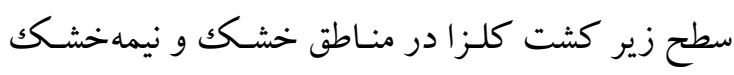
مؤثر باشد. نتسايج نشـان داد كـه بـرهمكنش زنوتيـبِ در تسنش

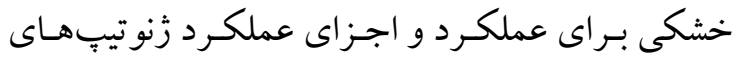

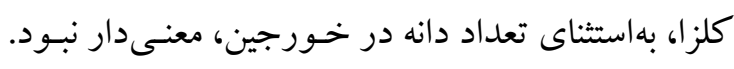

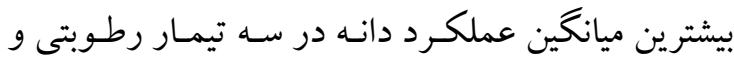

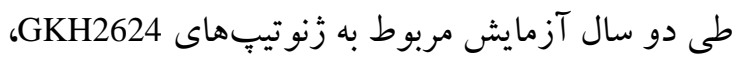

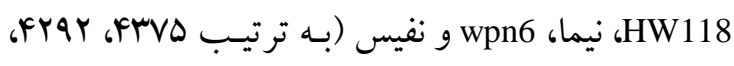
FIV • FYOI GYAF

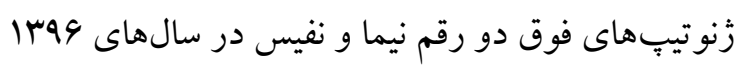

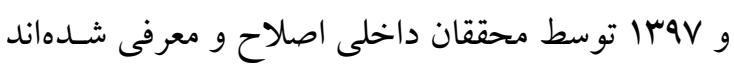

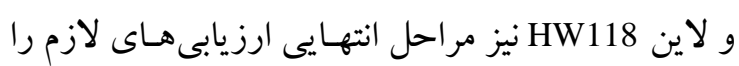


.(Naderi et al., 2000)

محاسبه برخى از شاخصهاى تحمـل خشـكى بـراى

زَنوتيڤ هاى كلزاى مورد بررسى در شرايط قطع آبيـارى

از مرحله كل دهى (جدول 9) نشان داد كـه زَنوتيبهـای

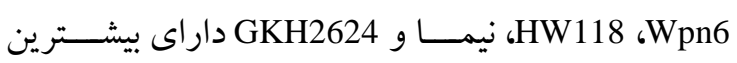

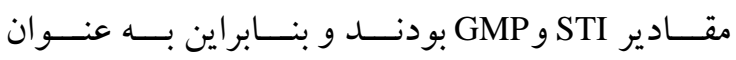

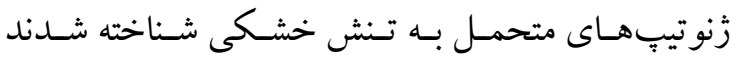

(جدول ه). زنوتيِهای اوكـايى، نفيس، Elvise، L155

و GKH2624 داراى كمترين مقدار SSI و TOL بودند و

بنابراين كمترين حساسيت به تنش خشكى را داشتند.
داراى يتانسيل عملكرد بالا و متحمـل بـه تسنش خشـى

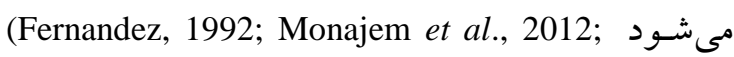

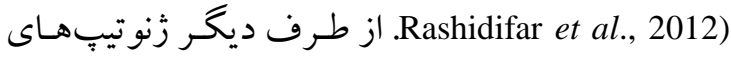

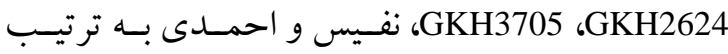
داراى كمترين شاخص حساسيت به تنش و TOL بودند. ارزيـابى زَنوتيـــهــا بـا اسـتفاده از شـاخص حساسـيت بـه تسنش، مـواد آزمايشسى را فقـط بـر اسـاس تحمـل و

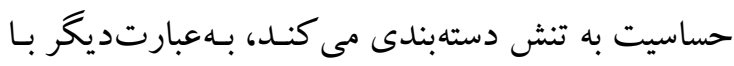
استفاده از اين شاخص مى تـوان زُنوتيـٍِهـاى حسـاس و متحمل را بلدون توجه به عملكرد آنهـا مشتصص كرد

جدول ه- شاخصهاى تحمل خشكى در زنوتيبٍ هاى كلز ادر تيمار قطع آبيارى از مرحله كلدهى

Table 5. Drought tolerance indices of oilseed rape genotypes in irrigation withhold from flowering stage treatment

\begin{tabular}{|c|c|c|c|c|c|c|c|c|}
\hline شماره & $\begin{array}{c}\text { رنوتيتهاى كلزا } \\
\text { Oilseed rape genotypes }\end{array}$ & Yp & Ys & TOL & MP & SSI & GMP & STI \\
\hline 1 & OPERA & 5081 & 2694 & 2387 & 3888 & 1.14 & 3700 & 0.51 \\
\hline 2 & Ahmadi & 4388 & 2388 & 2000 & 3388 & 1.11 & 3237 & 0.39 \\
\hline 3 & Nafis & 4981 & 3292 & 1689 & 4136 & 0.82 & 4049 & 0.61 \\
\hline 4 & Nima & 5614 & 3456 & 2158 & 4535 & 0.93 & 4404 & 0.72 \\
\hline 5 & KARAJ1 & 4788 & 2748 & 2040 & 3768 & 1.03 & 3627 & 0.49 \\
\hline 6 & OKAPI & 4410 & 3327 & 1083 & 3869 & 0.6 & 3831 & 0.55 \\
\hline 7 & GKH3705 & 5167 & 3108 & 2059 & 4137 & 0.97 & 4007 & 0.6 \\
\hline 8 & GKH2624 & 5365 & 3477 & 1887 & 4421 & 0.85 & 4319 & 0.7 \\
\hline 9 & GKH0224 & 5621 & 3259 & 2362 & 4440 & 1.02 & 4280 & 0.68 \\
\hline 10 & GABRIELLA & 4719 & 2853 & 1866 & 3786 & 0.96 & 3669 & 0.5 \\
\hline 11 & NEPTUNE & 5259 & 2919 & 2341 & 4089 & 1.08 & 3918 & 0.57 \\
\hline 12 & ELVISE & 4715 & 3081 & 1634 & 3898 & 0.84 & 3811 & 0.54 \\
\hline 13 & HW118 & 6064 & 3315 & 2749 & 4689 & 1.1 & 4483 & 0.75 \\
\hline 14 & HL2012 & 5535 & 3118 & 2418 & 4326 & 1.06 & 4154 & 0.64 \\
\hline 15 & WPN6 & 5842 & 3554 & 2288 & 4698 & 0.95 & 4556 & 0.78 \\
\hline 16 & L155 & 5247 & 3423 & 1825 & 4335 & 0.84 & 4238 & 0.67 \\
\hline 17 & HL3721 & 4973 & 1999 & 2974 & 3486 & 1.45 & 3153 & 0.37 \\
\hline 18 & KARAJ2 & 5362 & 2680 & 2682 & 4021 & 1.21 & 3791 & 0.54 \\
\hline
\end{tabular}

Yp: Yield potential, Ys: Yield under irrigation withhold, GMP: Geometric Mean

Productivity, SSI: Stress Susceptibility Index, STI: Stress Tolerance Index, TOL:

Tolerance Index, MP: Mean Productivity

عملكرد دانه اين زنو تيڤها در شـرايط آبيـارى كامـل و تنش خشكى از ميانكين عملكرد ساير زُنوتيِهـا بـالاتر بـود. در ايسن بـين زُنوتيبهــاى HW118، HKH2624 و

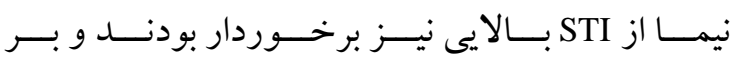
اسـاس تعريـف فرنانــز (Fernandez, 1992) متحمـل

$$
\begin{aligned}
& \text { نمودار سهبعدى بر اساس عملكرد در شرايط آبيارى }
\end{aligned}
$$

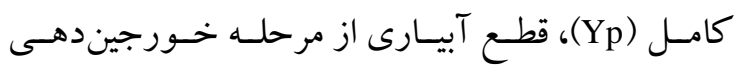

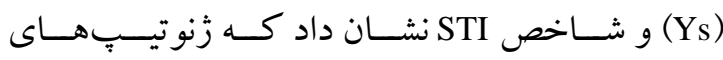

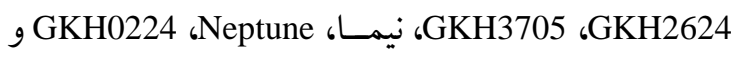

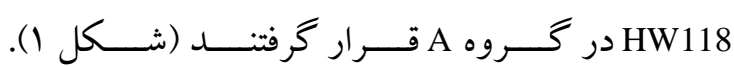




$$
\text { "نشريه علوم زراعى ايران"، جلد بيست و يكم، شماره F، زمستان هوسا }
$$

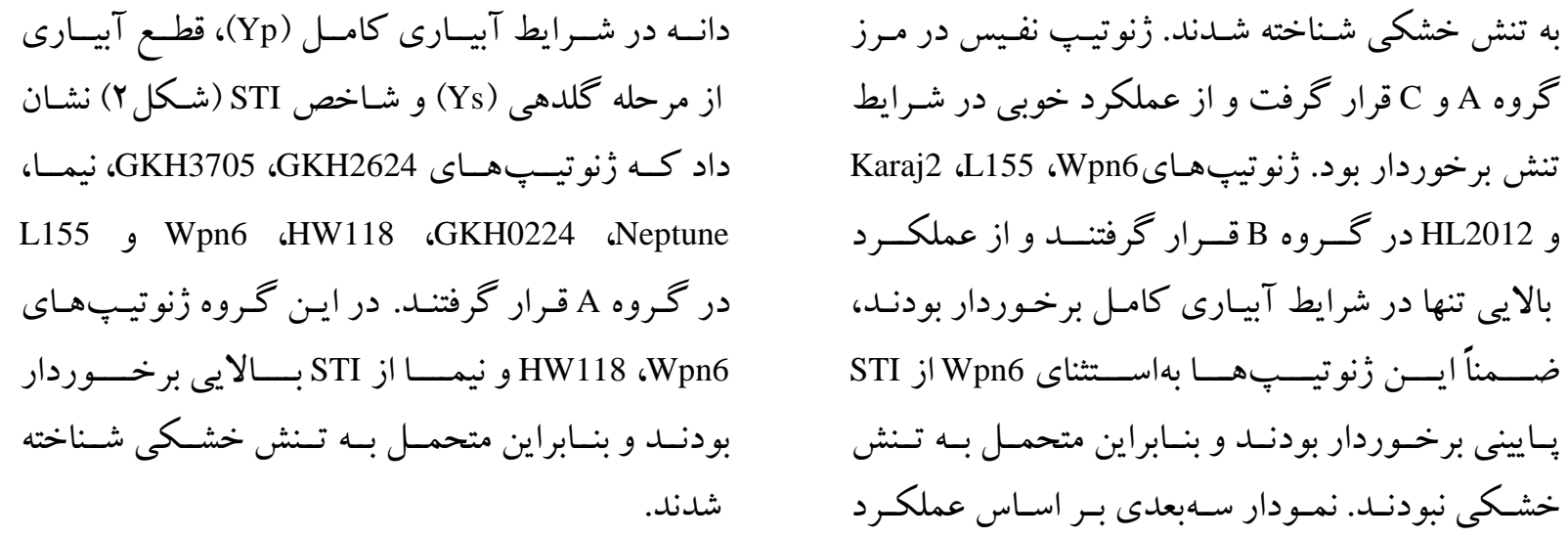

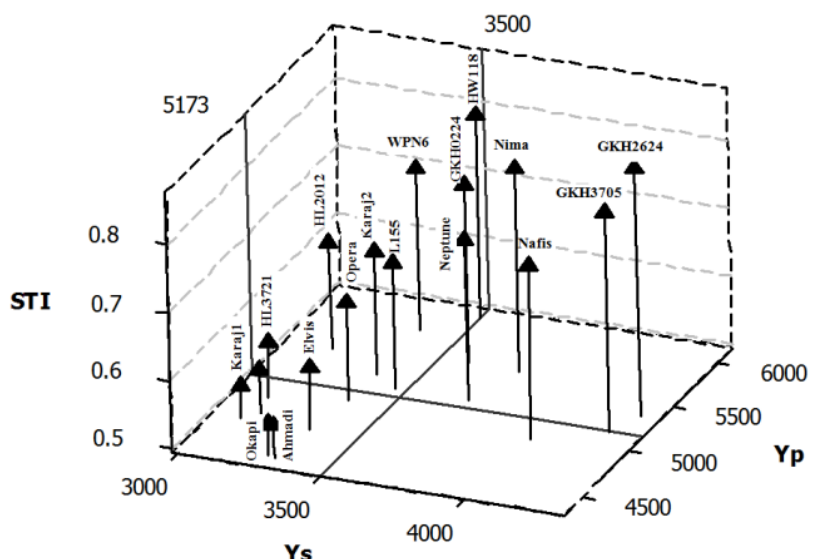

شكل 1- نمودار سهبعدى براكنش زنوتيبهاى كلزا بر اساس عملكرد دانه در شرايط آبيارى كامل (Yp)، عملكرد در

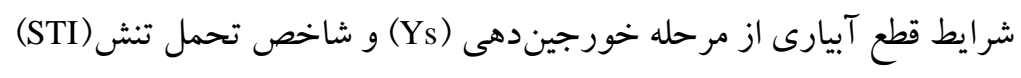

Fig. 1. 3-D diagram of distribution of oilseed rape genotypes based on grain yield under full irrigation (Yp), grain yield in irrigation withhold from silique development stage (Ys) and stress tolerance index (STI)

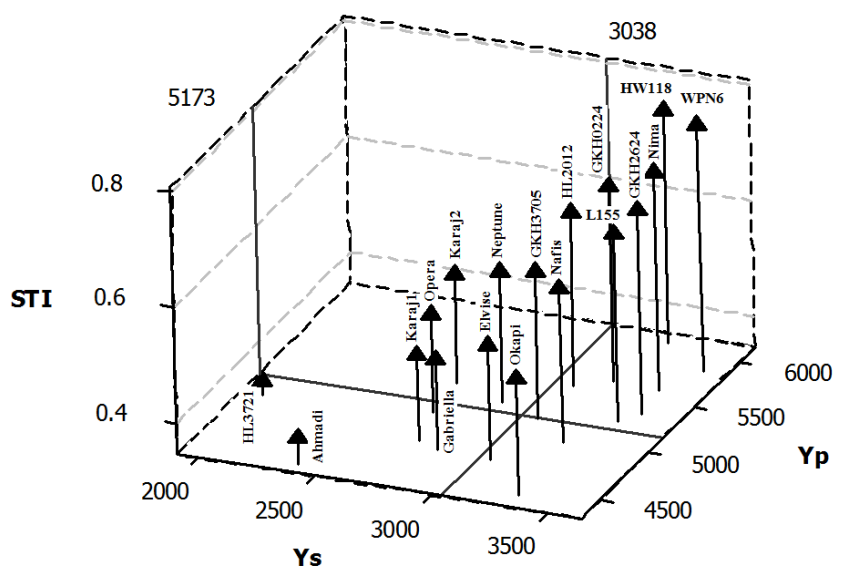

شكل r- نمودار سهبعدى براكنش زنوتيّهاى كلزا بر اساس عملكرد دانه در شر ايط آبيارى كامل (Yp)، عملكرد در

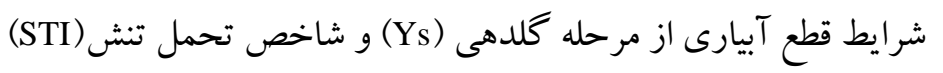

Fig. 2. 3-D diagram of distribution of oilseed rape genotypes based on grain yield under full irrigation (Yp), grain yield in irrigation withhold from flowering stage (Ys) and stress tolerance index (STI) 
به شاخصهاى SSI و TOL بود و انتخاب بر اسـاس ايسن

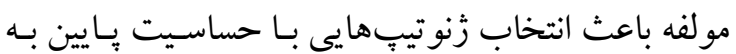
تنش مى شود. با توجه بـه بـاى بـالات منـتج از تجزيسه بـهـ

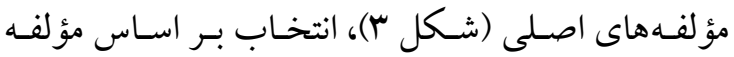
اصلى اول با توجه به جهت و زاويه بردارهاى مربوط بـه

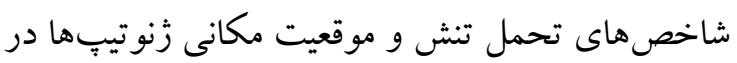

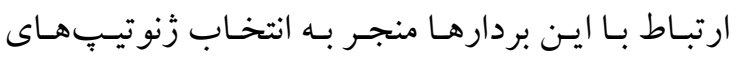

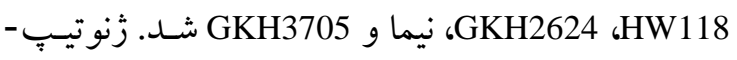
هاى مـذ كور داراى بيشـترين مقــادير بـراى STI و GMP بودنـــ. انتخـاب بـر اسـاس مؤلفـه اصـلى دوم منجـر بـــ انتخـاب زَنوتيـٍِهـاى GKH3705، نفسيس، GKH2624،

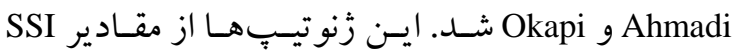
بايينى برخـوردار بودنــــ و در نتيجـه حساسـيت بـه تـنش يايني دارند. - تيند
انتخـاب بـر اسـاس تر كيبـى از شـاخصهاى تحمـل خشكى و عملكرد در شرايط تـنش و غيـر تسنش، باعـث انتخاب زَنوتيّهاى بـا عملكـرد بـالا در هـر دو شـرايط تسنش و غيـر تسنش مى شـود (Fernandez, 1992). بـراى منظور تجزيه به مؤلفه هاى اصلى بر اساس عملكـرد دانـه در شــرايط آبيـارى كامـل و قطـع آبيـارى از مرحلـه خورجيندهـى بـه بعـد و همجنــن شـاخص هاى تحمـل خشكى انجام شد. نتـايج نشـان داد كـه دو مؤلفـه اصـلى لـ اول بـيش از 99/9 درصــ از تغييـرات دادههــا را توجيـه كردند (جدول 9). بيشترين ضـرايب مؤلفـه اول متعلـق بـه شـاخص هاى

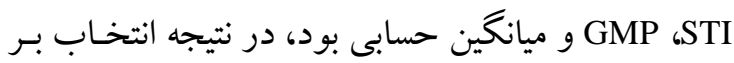

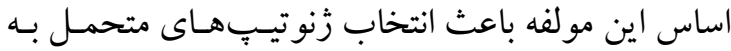
تنش خشكى مى شود. بيشترين ضرايب مؤلفه دوم متعلـق

جدول 9- تجزيه به مولفهاى اصلى براى شاخص هاى تحمل خشكى زنوتيبٍهاى كلزا در تيمار قطع آبيارى

$$
\text { از مرحله خورجيندهى }
$$

Table 6. Principal component analysis for drought tolerance indices of oilseed rape genotypes in irrigation withhold from silique development stage treatment

\begin{tabular}{|c|c|c|c|c|c|c|c|c|c|}
\hline $\begin{array}{c}\text { مؤلفه } \\
\text { Component }\end{array}$ & TOL & SSI & STI & GMP & MP & Yp & Ys & سهم تجمعى & $\begin{array}{c}\text { مقادير ويثه } \\
\text { Eigen values }\end{array}$ \\
\hline اولFirst & 0.07 & -0.05 & 0.48 & 0.48 & 0.48 & 0.38 & 0.38 & 0.61 & 4.29 \\
\hline دوم Second & 0.60 & 0.60 & -0.04 & -0.03 & 0.05 & 0.37 & -0.37 & 0.999 & 2.70 \\
\hline
\end{tabular}

جدول V- تجزيه به مولفههاى اصلى براى شاخص هاى تحمل خشكى زنوتيبٍ هاى كلزا در تيمار قطع آييارى از مرحله كلدهى

Table 7. Principal component analysis for drought tolerance indices of oilseed rape genotypes in irrigation withhold from flowering stage treatment

\begin{tabular}{|c|c|c|c|c|c|c|c|c|c|}
\hline $\begin{array}{c}\text { مؤلفه } \\
\text { Component }\end{array}$ & TOL & SSI & STI & GMP & MP & Yp & Ys & $\begin{array}{c}\text { سهم تجمعى } \\
\text { Cumulative proportion }\end{array}$ & $\begin{array}{c}\text { مقادير ويزٔه } \\
\text { Eigen values }\end{array}$ \\
\hline اولFirst & -0.04 & -0.22 & 0.46 & 0.46 & 0.45 & 0.35 & 0.43 & 0.66 & 4.6 \\
\hline دوم:Second & 0.65 & 0.57 & 0.05 & 0.03 & 0.14 & 0.42 & -0.23 & 0.999 & 2.4 \\
\hline
\end{tabular}

توجيـه كردنــــ. بيشـترين ضــرايب مؤلفــه اول بــراى شاخص هاى حساسيت به تنش، STI و GMP و بيشـترين ضرايب مؤلفـه دوم متعلـق بـه شـاخص هاى TOL و SSI

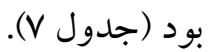

تجزيه به مؤلفههاى اصلي بر اساس عملكـرد دانسه در شرايط آبيارى كامل و قطع آبيارى از مرحله كلدهى بـه بعد و همجينين شاخص هاى تحمل خشكى نشان داد كـه دو مؤلفـه اصـلى اول بــش از 99/9 درصـــ دادههــا را 


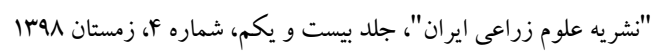

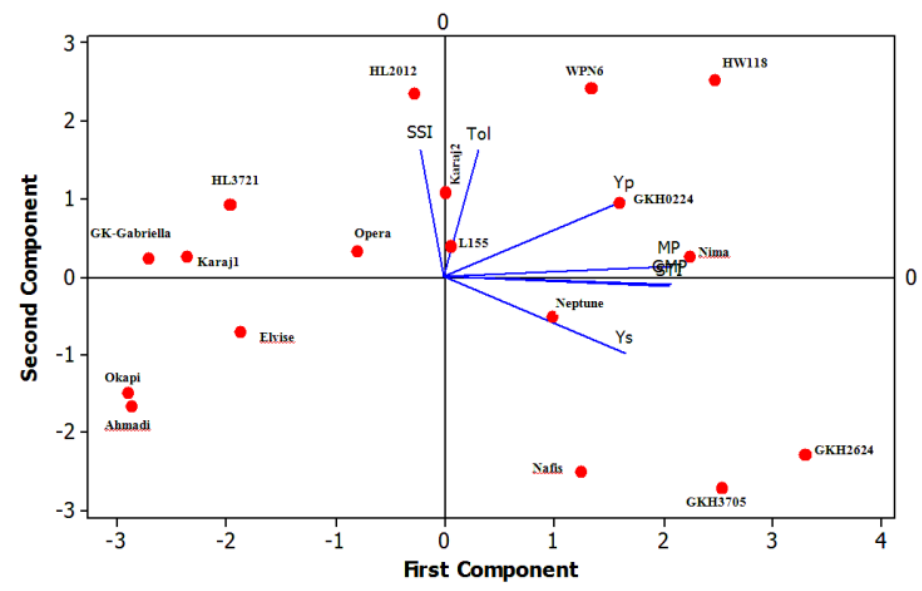

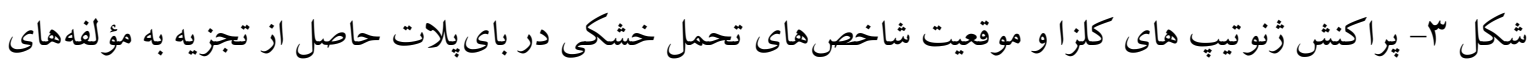

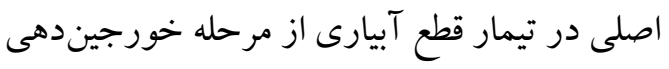

Fig. 3. Distribution of oilseed rape genotypes and the position of drought tolerance indices in the biplot derived from principal components analysis in irrigation withhold from silique development stage treatment

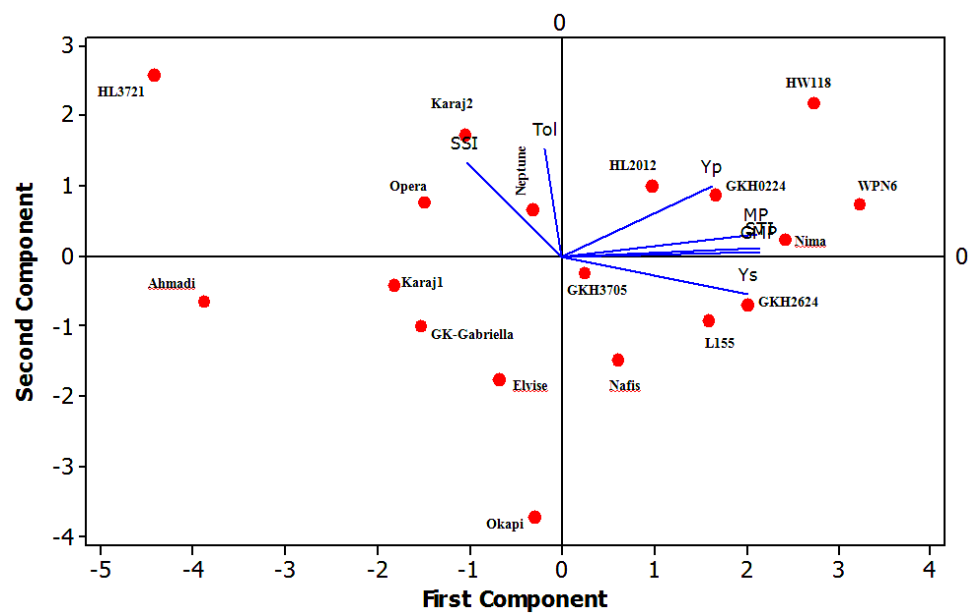

شكل ع- يراكنش زنوتيب هاى كلزا و موقعيت شاخصهاى تحمل خشكى در باىيلات حاصل از تجزيه به مؤلفهاى

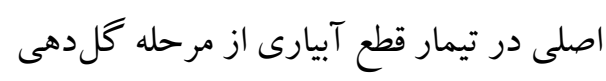

Fig. 4. Distribution of oilseed rape genotypes and the position of drought tolerance indices in the biplot derived from principal components analysis in irrigation withhold from flowering stage treatment

انتخـاب بـر اسـاس مؤلفـه اصلى دوم منجـر بـه انتخـاب

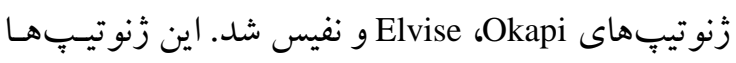

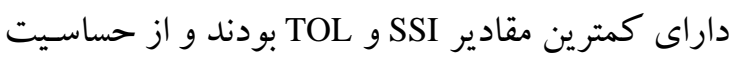

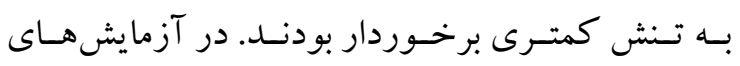

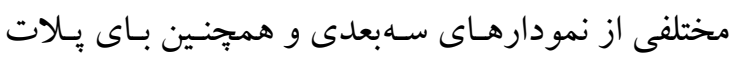
حاصل از تجزيه به مؤلفه هاى اصلى براى شناسايى ارقام
انتخاب بر اساس مؤلفه اصلى اول منجر بـه انتخـاب

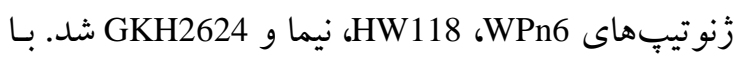
توجه به اينكه بيشترين ضرايب مولفـه اول در ايـن تيمـار

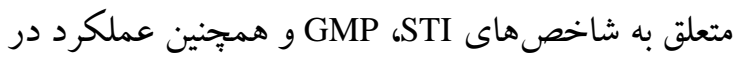

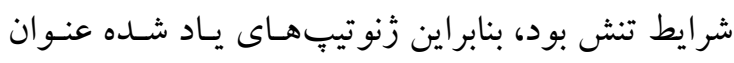

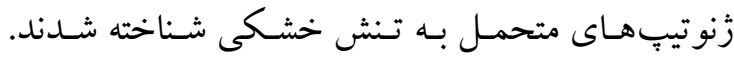


تجزيه باىيـالات و نمودارهـاى سـهبعدى، زنوتيـٍِهـاى

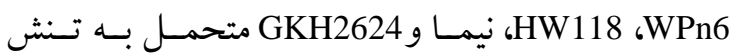
خشكى بودند، زيرا از STI بالايى برخوردار بودند. نكتـه مهام ديخرى كه در نتايج مشاهده شـد بـه رفتـار دو رقـم جديد نيما و نفيس و لاين در دست معرفى HW118 در تيمار آبيارى كامل و تنش خشكى برمى گردد. رقم نيمـا

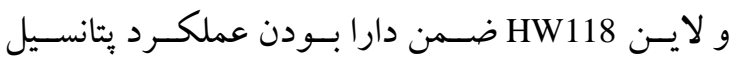
مناسـب در تيمـار آبيـارى كامـل در هـر دو تيمـار قطـع آبيارى از مرحلـه كلـدهى و خـورجيندهـى همـواره در ليسر

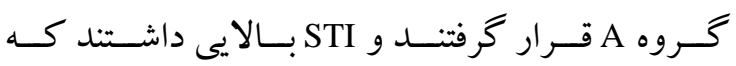
نشاندهنده تحمل بالاى اين زنوتيّها به تـنش خشكى مىباشد. رقم نفيس نيز همواره در كروه C قرار كرفت

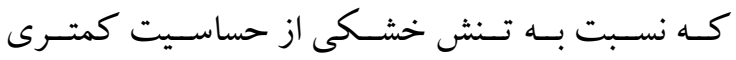
برخــوردار بــود و نتـايج آزمـايش حاضـر تأيــدى بــر ويز گیىهاى مثبت اين دو رقم براى معرفى بهعنوان ارقام جديد و تأكيد بر استفاده از اين ارقام در منـاطق سـرد و معتدل سرد كشور مىباشد. از بـين هيبريسدهاى خـارجى كه هم اكنون در سطح وسـيع در منـاطق سـرد و معتــل سـرد كشــور كشـت مى شــوند، هيبريســ Neptune از عملكرد نسبتا مناسبى در هـر دو تيمـار آبيـارى كامـل و تنش خشكى برخوردار بود، در حالى كه ديكـر هيبريــ خارجى (Elvise) از يتانسيل عملكـرد يـايينى در شـرايط آبيارى كامل برخـوردار بـود و عملكـرد آن در شـرايط تنش نيز متوسط ارزيابى شد.

\section{سياسگز ارى}

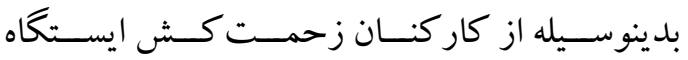
تحقيقـات كشـاورزى اسـلام آبـادغـرب كـه در اجـراى يزو هش حاضر نقش موثرى داشتند، قدردانى مىشود.

\section{References}

زراعى متحمـل بـه تسنش خشكى اسـتفاده شـده اسـت

(Dehghani et al., 2009; Rashidifar et al., 2012; Hosseini 2016; Majidi et al. 2015; Rashidi et al., (2017 و نتــايج آزمــايش حاضـر بــا آنهـا تطسابق دارد.

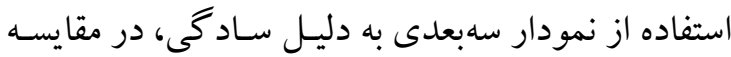
بـا بـاى يـالات بيشـتر اسـت، هـر جنـــ روش بـاى يـلات

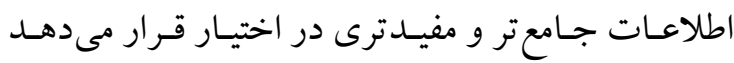
(Dehghani et al., 2009) نتـايج نمـودار ســبعلى و همجينين باى يلات هـاى بهدسـت آمده در دو تيمـار تسنش خشكى نشان داد كـه علـىرغم اينكـه ميـانخين مربعـات

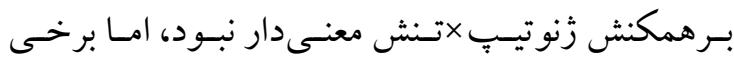
از زنوتيٍٍ ها در دو تيمار تسنش خشكى رفتـار متفـاوتى داشـته و در كروههــاى مختلفـى قـرار كر فتنـد. بعنـوان مثـال زنوتيـيّهــاى Neptune و H12012 در تيمـار قطـع آبيارى از مرحله خورجيندهى در كروه B قرار كرفتند، در حالى كه در تيمار قطع آييارى از مرحلـه كلـدهى در كروه A قرار كرفتند. در آزمـايش رشـيدى و همكـاران نيـز كـه كونسههـاى مختلـف (Rashidi et al., 2017) كلـزا در شـرايط تسنش شـديد و ملايــم خشـكى مـورد ارزيابى قـرار گرفتنـ، برخسى از گونسهــا و ارقـام كلـزا

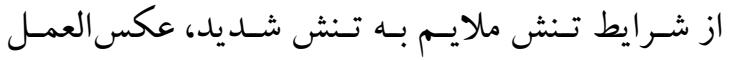
متفاوتى داشتند. نتـايج حاصـل از نمودارهـاى سـهبعدى و بـاى يـلات تطـابق نسـبتاً خـوبى بـاهم داشـتند، ضـمن اينكه اطلاعات بهدست آمده از نمودار باى يـلات بيشـتر

\section{نتيجه Fيرى}

نتايج اين آزمايش نشان داد كه در تيمار تنش شديد خشكى (قطع آبيارى از مرحله كـلدهـى) و بـر اسـاس

Blum, A. 2012. Drought Resistance, In: Blum, A. (Ed.), Plant Breeding for Water-limited Environments. Springer, New York, Dordrecht Heidelberg London.

Chen, S., M. Nelson, K. Ghamkhar, T. Fu and W. Cowling. 2008. Divergent patterns of allelic diversity from 


$$
\text { "نشريه علوم زراعى ايران"، جلد بيست و يكم، شماره F، زمستان 1هץ| }
$$

similar origins: the case of oilseed rape (Brassica napus L.) in China and Australia. Genome, 51: 1-10.

Daneshmand, A. R., A. H. Shirani Rad and M. R. Ardakani. 2006. Evaluation of water deficit stress on tolerance of spring rapeseed (Brassica napus L.) genotypes. J. Agron. 1 (1): 48-60. (In Persian with English abstract).

Dehghani, Gh., F. Malekshhi and B. Alizadeh. 2009. A study of drought tolerance indices in canola (Brassica napus L.) genotypes. J. Sci. Tech. Agric. Natur. Resour. 13(48): 77-90. (In Persian with English abstract).

Delkhosh, B., A. H. Shirani Rad, Z. Bitarafan and G. Mousavi nejad. 2012. Drought stress and sowing date effects on yield and some grain traits of rapeseed cultivars. Adv. in Environ. Biol. 6(1): 49-55.

Diepenbrock, W. 2000. Yield analysis of winter oilseed rape (Brassica napus L). Field Crops Res. 67: 35-49

Fahad, SH., A. Bajwa, U. Nazir, SH. A. Anjum, A. Farooq, A. Zohaib, S. Sadia, W. Nasim, S. Adkins, SH. Saud, M. Z. Ihsan, H. Alharby, CH. Wu, D. Wang and J. Huang. 2017. Crop production under drought and heat stress: Plant responses and management options. Front. Plant Sci. 8: 1-16.

FAOSTAT. 2017. Statistical Database of the Food and Agriculture Organization of the United Nations. FAO, Rome, Italy.

Farooq, M., A. Wahid, N. Kobayashi, D. Fujita and M. A. Sbasra. 2009. Plant drought stress: effects, mechanisms and management. Agron. Sustain. Dev. 29: 185-212.

Fernandez, G. C. J. 1992. Effective selection criteria for assessing plant stress tolerance. In: Kuo, C. C. (Ed.) Proceedings of International Symposium on Adaptation of Food Crops to Temperature and Water Stress. Shanhua, Taiwan, 257-270.

Fischer, R. A. and R. Mourer. 1978. Drought resistance in spring wheat cultivar. I: grain yield responses. Aust. J. Agric. Res. 29: 897-912.

Ghobadi, M., M. Bakhshandeh, G., Fathi, M. H., Gharineh, Kh., Alami-Said, A., Naderi and M. E. Ghobadi. 2006. Short and long periods of water stress during different growth stages of canola (Brassica napus L.): effect on yield, yield components, seed oil and protein contents. J. Agron. 5: 336-341.

Hamed, A., G. A. Akbari, N. A. Khosh Kholgh Sima, A. H. Shirani Rad, H. Jabbari and A. Tabatabaee, 2015. Evaluation of the agronomic characteristics and some physiological traits of canola varieties under drought stress. Environ. Stresses Crop Sci. 7(2): 155-171. (In Persian with English abstract).

Honar, T., A. Sabet Sarvestani, SH. Shams, A. R. Sepaskhah and A. A. Kamgar Haghighi. 2013. Effect of drought stress in different growth stages on grain yield and yield components of rapeseed (cv. Talayeh). Iran. J. Crop Sci. 14(4): 320-332. (In Persian with English abstract).

Hosseini, S. Z. 2016. Evaluation of drought tolerance in canola (Brassica napus L.) genotypes, using biplot analysis. J. Crop Breed. 8(19): 1192-202. (In Persian with English abstract).

Jabbari, H., G. A. Akbari, N. A. Khosh Kholgh Sima A. H. Shirani Rad, I. Alahdadi, I. and F. Tajodini. 2015. Study of agronomical, physiological and qualitative characteristics of canola (Brassica napus) under water stress. Environ. Stresses Crop Sci .8(1): 35-49. (In Persian with English abstract). 
"ارزيابى رشد و عملكرد دانه زنوتيبهاى....، رضايى زاد و همكاران،

Karimzadeh, R. and M. Mohammadi. 2011. Association of canopy temperature depression with yield of durum wheat genotypes under supplementary irrigated and rainfed conditions. Aust. J. Crop Sci. 5: 138-146.

Majidi, M. M., M. Jafarzadeh Ghahdrijani, F. Rashidi and A. Mirlohi. 2015. Identification of canola cultivars with drought tolerance indices. Iran. J. Field Crop Sci. 45(4): 565-573. (In Persian with English abstract).

Monajem, S., V. Mohammadi and A. Ahmadi. 2012. Evaluation of drought tolerance in some rapeseed Cultivars based on stress evaluation indices. J. Crop Prod. 4 (1): 151-169. (In Persian with English abstract).

Naderi, A., I. Majidi-Hervan, A. Hashemi Dezfouli, A. Rezaei and Gh. Nourmohammadi. 2000. Efficiency analysis of indices for tolerance to environmental stresses in field crops and introduction of new index. Seed Plant J. 15(4): 390-402. (In Persian with English abstract).

Pantuwan, G., S. Fukia, M. Cooper, S. Rajatasereekul and J. C. OToole. 2002. Yield response of rice (Oryza Sativa L.) genotypes to drought under rainfed lowlands. 2. Selection of drought resistance genotypes. Field Crops Res. 73: 169-180.

Rashidi, F., M. M. Majidib and M. Pirboveiryc. 2017. Response of different species of Brassica to water deficit. Int. J. Plant Prod. 11 (1): 1-16.

Rashidifar, J., H. Dehghani and B. Alizadeh. 2012. Evaluation of drought tolerance in some of winter canola cultivars. Iran. J. Field Crops Res. 20 (2): 456-467. (In Persian with English abstract).

Richard, R. A. 1978. Variation between and within species of rapeseed (Brassica compestris and B. napus) in response to drought stress. Aust. J. Agric. Res. 29: 491-501.

Richard, R. A. and N. Thrling. 1978. Variation between and within species of rapeseed (Brassica compestris and B. napus) in response to drought stress. II. Growth and development under natural drought stress. Aust. J. Agric. Res. 29: 479-490.

Rosielle, A. A. and J. Hamblin. 1981. Theoretical aspects of selection for yield in stress and non-stress environments. Crop Sci. 21: 943-946.

Shampolivier, L. and A. Merrien. 1996. Effects of water stress applied at different growth stages to Brassica napus 1. Var Olieifera on yield, yield components and seed quality. Europ. J. Agron. 5: 153-160.

Shirani Rad, A. H. and M. Zandi. 2012. The effect of drought stress on qualitative and quantitative traits of spring rapeseed (Brassica napus L.) cultivars. Agriculture. 99 (1): 47-54.

Sinaki, J. M., I. Majidi Heravan, A. H. Shirani Rad, G. Noormohamadi and G. Zarei. 2007. The effects of water deficit during growth stages of canola (B. napus L). American-Eurasian J. Agric. Environ. Sci. 2(4): $417-422$

Tesfamariam, E. H., J. G. Annandale and J. M. Steyn. 2010. Water stress effects on winter canola growth and yield. Agron. J. 102 (2): 658- 666. 
"نشريه علوم زراعى ايران"، جلد بيست و يكم، شماره "ج، زمستان هوبا

\title{
Evaluation of growth and seed yield of new winter oilseed rape (Brassica napus L.) genotypes under terminal drought stress conditions
}

\author{
Rezaizad, A. ${ }^{1}$, A. Zareei Siahbidi ${ }^{2}$ and A. H. Shirani Rad $^{3}$
}

\begin{abstract}
Rezaizad, A., A. Zareei Siahbidi and A. H. Shirani Rad. 2020. Evaluation of growth and seed yield of new winter oilseed rape (Brassica napus L.) genotypes under terminal drought stress conditions. Iranian Journal of Crop Sciences. 21(4): 328343. (In Persian).
\end{abstract}

Breeding and production of drought tolerant cultivars for arid and semi-arid area is very important. The present experiment was carried out to evaluate the effects of drought stress on seed yield and yield components of oilseed rape as well as identification of high yielding and drought stress tolerant genotypes. Eighteen new winter oilseed rape lines and commercial cultivars were evaluated under three moisture conditions in two cropping seasons (2014-2016) in agricultural research station of Islamabad-e-Gharb, Kermanshah, Iran. The three moisture conditions included: full irrigation, irrigation withhold from the flowering and from silique development stages. Results showed that among the yield components, numbers of seeds per silique and 1000 seed weight were significantly affected by drought stress. The reduction in 1000-seed weight under irrigation cut off from silique development stage and flowering stage was $12.8 \%$ and $24.4 \%$, respectively. Cumulative reduction in yield components under drought stress conditions caused a significant decrease in grain yield by $32.3 \%$ and $41.3 \%$, under irrigation cut off from silique development and flowering stage, respectively. Correlation analysis showed that there was a weak relationship between yield in full irrigation and drought stress conditions, therefore, using drought tolerance indices to screen genotypes with high yield potential and drought stress tolerant is essential. Three dimensional diagrams based on seed yield in full irrigation condition, irrigation cut off condition from silique development stage and STI showed that genotypes GKH2624, GKH3705, Nima, Neptune, GKH0224 and HW118 were located in group A, while under irrigation cut off condition from flowering stage genotypes GKH2624, GKH3705, Nima, Neptune, GKH0224, HW118, Wpn6 and L155 were classified in group A. In general, according to biplot derived from principal components analysis and 3-D graphs, under severe drought stress (irrigation cut off from flowering stage), genotypes WPn6, HW118, Nima and GKH2624 were identified as drought tolerant genotypes with high yield potential.

Key words: Biplot, Drought stress, Seed yield, Oilseed rape and Principle components analysis.

\footnotetext{
Received: January, 2019 Accepted: June, 2019

1. Associate Prof., Field and Horticulture Crops Sciences Research Department, Kermanshah Agricultural and Natural Resources Research and Education Center, AREEO, Kermanshah, Iran (Corresponding author) (Email: arezaizad@yahoo.com)

2. Assistant Prof., Field and Horticulture Crops Sciences Research Department, Kermanshah Agricultural and Natural Resources Research and Education Center, AREEO, Kermanshah, Iran

3- Professor, Seed and Plant Improvement Institute, Agricultural Research, Education and Extension Organization, Karaj, Iran
} 